\title{
APR 111975
}

DIV. of GEOL SURVEY

\section{ONITED STATES DEPARTMENT OF THE INTERIOR}

GEOLOGICAL SURVEY

\begin{abstract}
GBOLOGICAL SURVEY AND SELECTED U.S. BUREAU OF MUNES AND ALASRA DIVISION OF GEOLOGICAL AND GEOPHYSICAI SURVEYS REPORTS AND MAPS ON ALASKA RELEASED DURING 1974, INDEYRD BI QUADRANGLE
\end{abstract}

By

Edward B. Cobb

Open-f1le report - 75-128

1975

This report is preliminary and has not been edited or revlewed for conformity with Geological Survey standards 
Introduction - 1

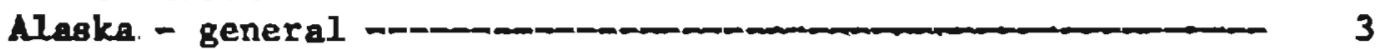

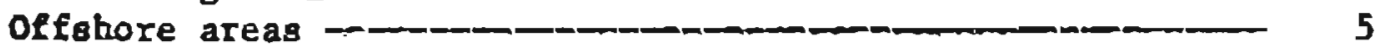

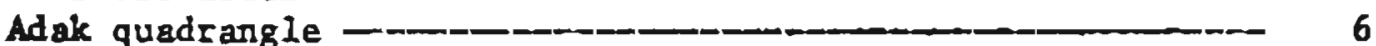

Afognak quadrangle _-n 6

Ambler River quadrangle _- 6

Amukta quadrangle - 6

Anchorage quadrangle - 6

Atka quadrangle _-______ 7

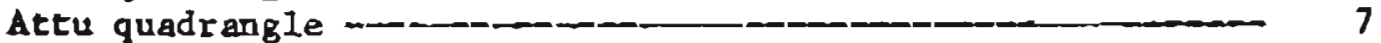

Balrd Inlet quadrangle - 8

Ba1rd Mountalns quadrangle - 8

Barrow quadrangle - 8

Barter Island quadrangle - _-_ 9

Beaver quadrangle - 9

Beechey Point quadrangle - 10

Bendeleben quadrangle - 11

Berlng Glacler quadrangle -__ 11

Bethel quadrangle -__________ 11

Bettleg quadrangle _-___________ 12

B1g Delta quadrangle -_-___- 12

Block quadrangle _-_________ 12

Bradfleld Canal quadrangle _-_ 13

Br1sto1 Bay quadrangle - 13

Candle quadrangle - 13

Cape Mendenhal1 quadrangle _-____ 13

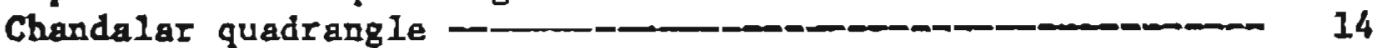

Chandler Lake quadrangle ________________ 14

Charley RIver quadrangle - 14

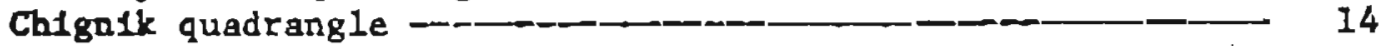

Christian quadrangle - 15

Circle quadrangle --_- 15

Cordova quadrangle - 15

Craig quadrangle - 16

De Long Mountalns quadrangle - 16

Demarcation Polnt quadrangle - 16

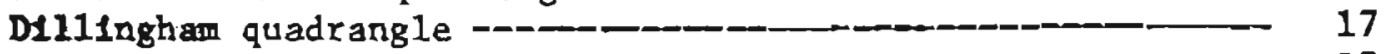

D1xon Batrance quadrangle _- 17

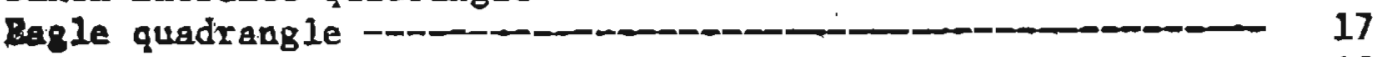

Falrbanks quadrangle _-________________ 18

Palae Pass quadrangle - 18

Flexman Igland quadrangle 18

Garelo1 Island quadrangle.-- 19

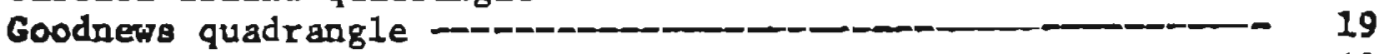

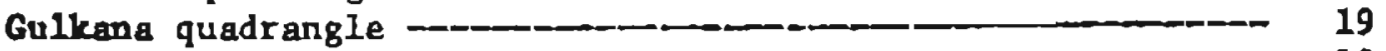

Hageme 1Bter Island quadrangle - 19

Barribon Bay quadrangle - 20

Bealy quadrangle -..._- 20

Eoly Cross quadrangle - 20 
Hooper Bay quadrangle - 20

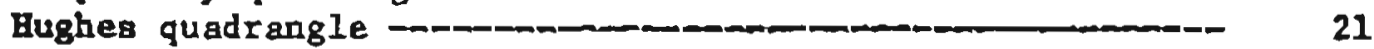

Id1tarod quadrangle _.__ 21

Ikplkpuk Rlver quadrangle - 21

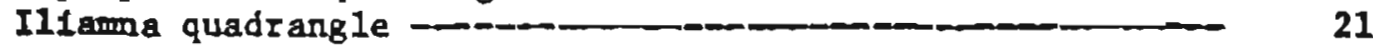

Juneau quadrangle _.__________ 22

Kantiohna River quadrangle _. 22

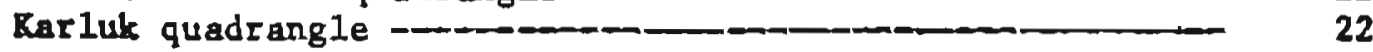

Kenat quadrangle an_- 23

Ketchtkan quadrangle _-______________ 23

R1Ilik River quadrangle _- 24

K1ska quadrangle _-___________________________ 24

Rod1ak quadrangle _-_________ 24

Ruskokw1m Bay quadrangle _ _ _ 24

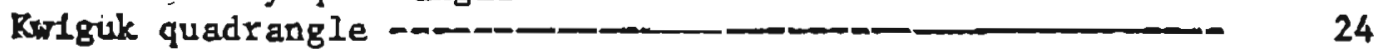

Lake Clark quadrangle _-____________ 25

LIme HIlls quadrangle _-_ 25

LIvengood quadrangle - - 26

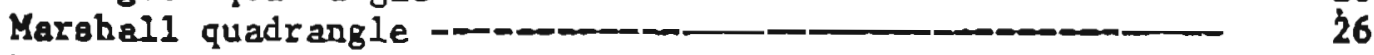

McCarthy quadrangle -a_n____ 26

McGrath quadrangle -____ 27

Meade Rtver quadrangle - 27

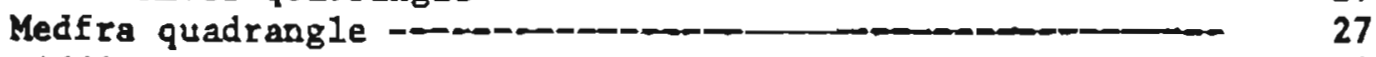

Mtddleton Ialand quadrangle - _ 28

Mloheguk Mountain quadrangle - 28

Mount Falrweather quadrangle -_-___-___- 28

Mount Hayes quadrangle - 28

Mount Katma1 quadrangle -__n______ 29

Mount Mckinley quadrangle - _ _ 29

Mourit Michelson quadrangle _-__________ 29

Nabesna quadrangle -_______________ 30

Nakonek quadrangle -

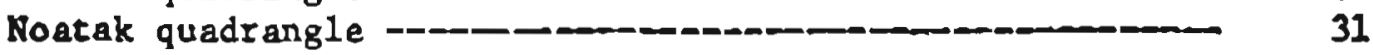

Nome quadrangle - 31

Norton Bay quadrangle _-___________ 31

Nulato quadrangle 31

Ninlvak Island quadrangle -_- 32

Nuohagak Bay quadrangle -________ 32

Ophtr quadrangle _-_ 32

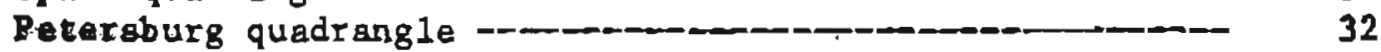

Ph111p Sm1th Mountalns quadrangle - _ 33

Polnt Hope quadrangle _...._________ 33

Polnt Lay quadrangle _-_____ 33

Port Alexander quadrangle - 34

Port Moller quadrangle -

Pribllof Islands quadrangle - _ 34

Prince Rupert quadrangle - 34

Rat Isiands quadrangle - 35

Ruby quadrangle - 35

Buselan Mission quadrangle 35 
Sagavan1rktok quadrangle _- _

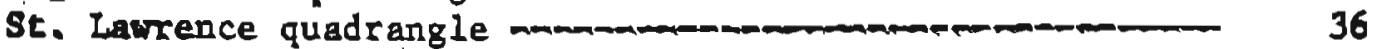

St. Matthew quadrangle - 36

3t. Michael quadrangle _-________ 37

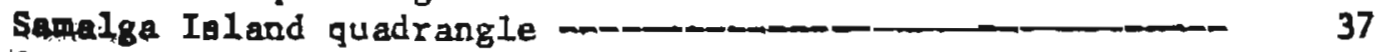

Seguam quadrangle -___________ 37

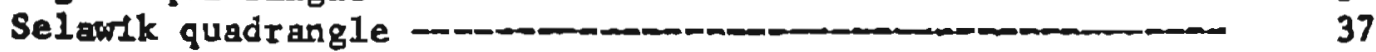

Seldovla quadrangle - 37

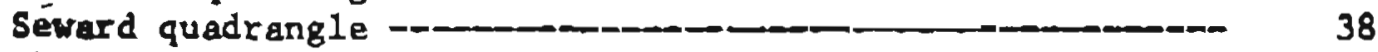

Shlohmaref quadrangle - _ 38

Shungnak quadrangle - 38

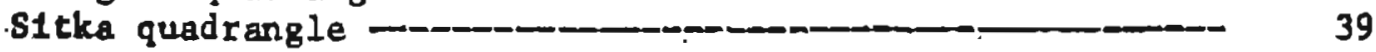

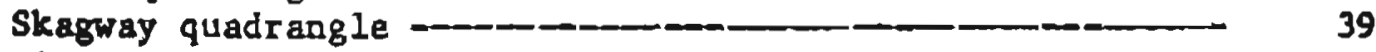

Sleetmute quadrangle - 39

Solomon quadrangle ____________________ 39

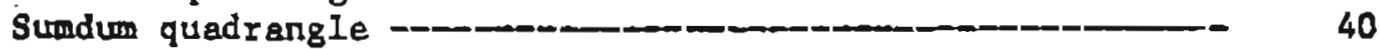

Survey Pasa quadrangle - _-_ 40

Table Mounta1n quadrangle - 40

Taku RAver quadrangle _-_ 40

Talkeetna quadrangle - 41

Talkeetna Mountalns quadrangle - 41

Tenacross quadrangle _ 42

Tanana quadrangle -_- 42

Taylor Mountalng quadrangle -.____ 42

Teller quadrangle -

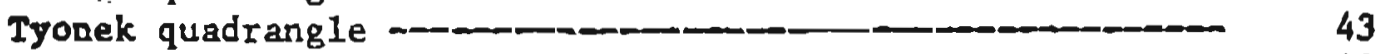

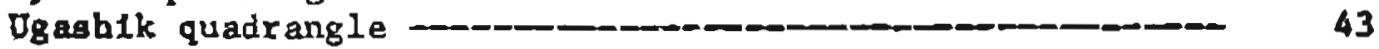

Unmak quadrangle - 44

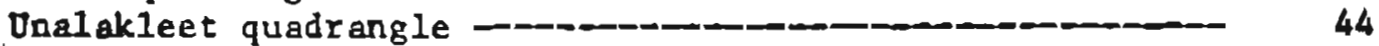

Unalaska quadrangle - 44

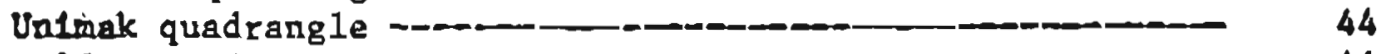

Valdez quadrangle - 44

Walmught quadrangle - 45

Wiseman quadrangle - 45 
Geologlcal Survey and selected U.S. Bureau of Mines and Alaska Division of Geological and Geophysical Surveys reports and maps on Alaska released during 1974. lndexed by quadrangle

By Edward H. Cobb

Introduct 1 on

Al1 Geologlcal Survey reports and maps on Alaska published or released to open files during 1974 are listed by the quadrangle (scale 1:250,000) 1nto whlch Alaska has been divided for topograph1c mapping (p. 2). Also 11sted are U.S. Bureau of Mines reports on the geology and mineral resources of Alaska, but not those deallng exclusively with other subjects such as economica. Alaska Division of Geological and Geophysical Surveys published reports on geology and mineral resources are 11sted, but those released to open f1les are not. Th1s 18 because all open-f1le reports and maps were withdrawn in 1974 for reviston, consolidation, or assignment of new identification numbers before possible relsaue. At the time of preparation of this index I had recelved so few newily released open-file reports that I felt that lncluding any of them might cause confuston to potential users because of possible duplication of. titles or numbers.

Most of the reports and maps in this 1ndex bear a 1974 1mprint date. Others bear earlier lmprint dates, but release was not announced unt1l 1974. A few that were released before 1974, but escaped my attention at that time, are aloo included here.

Reports that deal with Alaska as a whole, with aress that cannot be Identifled with any specific quadrangle, or that consist mainly of statigtical data on the quantity or quality of water are listed under AlASRA - GENERAL, as are Indexes and the like. Reports that deal with offabore areas not within quadrangle boundarles are listed under ofFSHORE AREAS. The ALASKA - GENERAL and OFFSHORE AREAS 11 sts appear before the alphabetically arranged quadrangle listings.

Th1s 1ndex 18 1ntended to bring up to date the 1ndexes I1sted under Cobb, 1974, In the ALASKA - GENERAI section of this 1ndex. 


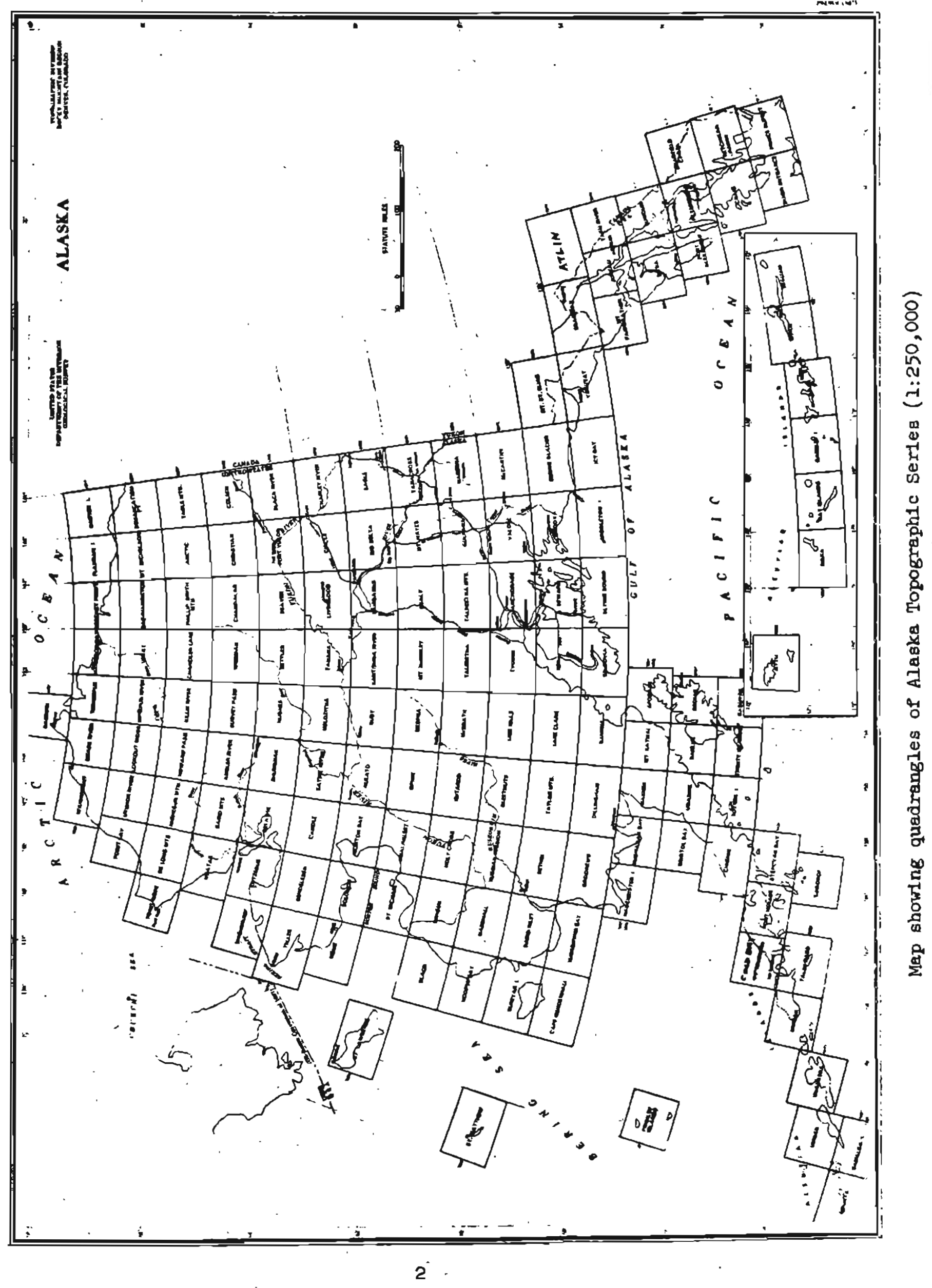




\section{AIASKA - GENERAL}

Alaska Division of Geological and Geophysical Surveys, 1974, Annual Report 1973: Anchorage, Alaska, 59 p.

Boerngen, J. G., Kemilton, J. C., Marsh, W. R., and Rosenblum, sam, 1974, Description of magnetic tape containing results of semiquantitative spectrograph1c analyses of the nonmagnet1c fractions of 1,069 Alasican alluvial concentrates: Natl. Tech. Inf. Service PB-23I 513/AS, $24 \mathrm{p}$.

Bottge, R. G., 1974, Potential mineral resources in selected 0.2 lands: U.S. Bur. Mines open-file rept. 9-74, 55 p. Also released as Natl. Tech. Inf. Service PB 227 018/AS.

Brew, D. A., 1974, Environmental impact analysis! the example of the proposed trans-Alaska pipeline: U.S. Ceol. Survey C1rc. 695, 16 p.

carter, claire, ed., 1974, United States Geological Survey Aleska Program, 1974: U.S. Geol. Survey C1re. 700, 63 p.

Cobb, E. H., 1974, Synopsis of the mineral resources and geology of Alaska: U.S. Geol. Survey Eull. 1307, 53 p.

Cobb, E. H., 1974, Index of metallic mineral deposits of Alaska compiled from published reports of federal and State agencles through 1972: Natl Tech. Inf. Service PB-233 217/AS, 590 p.

Cobb, E. H., 1974, Geologlcal Survey open-f1le reports on Alaska Indexed by quadrangle: U.S. Geol. Survey open-file report 74-7, $116 \mathrm{p}$.

cobb, E. H., 1974, Selected U.S. Bureau of Mines reports on Alaska indexed by quadrangle! U.S. Geol. Survey open-f1le report 74-52, - 40.

Cobb, E. H., 1974, Geologlcal survey maps (otber than topographic maps) of Aleska indexed by quadrangle: U.S. Geol. Survey openp1le report $74-84,38 \mathrm{p}$.

Cobb, E. B., 1974, Reports of the Alaska Division of Geological and Geophys1cal Surveys ana predecessor agencles, 1913-1973, Indexed by quadrangle: U.S. Geol. Survey open-f1le report 74-209, 112 p.

cobb, E. R., 1974, Geologlcal survey published reports on Alaska, 1960-1973, Indexed by quadrangle: U.S. Geol. Survey open-file report $74-210,163 \mathrm{p}$.

cobb, E. H., 1974, Geological survey published reports on Alaska, 1940 1959, indexed by quadrangle: U.S. Geol. Survey open-file report $74-261,71 \mathrm{p}$.

Cobb, E. H., 1974, Geological Survey published reports on Alaska, 1915-1939, 1ndexed by quadrangle: U.S. Geol. Survey open-P1le report $74-335,159 \mathrm{p}$.

Cobb, E. H., 1974, Geologlcal survey published reports on Alaska, 18841914, Indexed by quadrangle: U.S. Geol. Survey open-file report $74-345,126$ p. 


\section{ALASTRA - GENERAL}

Cobee, G. V., and Wrlght, H. B, 1974, Changes in stratigraphlc nomenclature by the U.S. Geological Survey, 1972! U.S. Geol. Survey Bull. 1394-A, p. Al-A93.

Crump, L. H., and Readling, C. L., 1974, Fuel and energy data: Untted States by states and regions, 1972: U.S. Bur. Mines Inf. CIrc. $8647,82 \mathrm{p}$.

Csejtey, Béla, Ir., 1974, Reconnaissance geologic invest1gations in the Talkeetna Mountalns, Alaska: U.S, Geol. Survey open-f1le report 74-247, 48 p.

Dey, G. W., CrIm, W. D., Rosenblum, Sam, Overstreet, W. C., and Larson, A. L., 1974, Magnetic tape containing results of semquantitative spectrographic analyses of the magnetic fractions of 680 Alaskan alluvial concentrates: Natl. Tech. Inf. Service. PB-229 947/AS, magnet1c tape.

Detterman, R. L., and Reed, B. L., 1973, Surf1c1al deposits of the Illana quadrangle, Alaska: U.S. Geod. Survey Bull. 1368-A, p. AlA64.

Foster, H. L., and Kelth, T. E. C., 1974, Ultramaflc rocks of the Eagle quadrangle, east-central Alasks: U.S. Geol. Survey Jour. Research, v.:2, no. 6, p. 657-669.

Hamilton, J. C., Boerngen, J. G., Mersh, W. R., and Rosenblum, Sam, 1974, Magnetic tape containing results of semiquantitative spectrographic analyses of 1,069 Alaskan alluvial concentrates: Natl. Tech. Inf. Service PB-231 246, magnetic tape.

Iser1, K. T., and Langbein, W. B., 1974, Large rivere of the Un1ted States: U.S. Geol. Survey C1rc. 686, 10 p.

Paone, James, Morning, J. L., and Glorgett1, Leo, 1974, Land use and reclemation in the mining 1ndustry, 1930-71: U.S. Bur. Mines Ins. C1rc. $8642,61 \mathrm{p}$.

Reed, B. L., and Lanphere, M. A., 1974, Chemfeal varlattons across the Alaska-Aleutian Range bathollth: U.S. Geol. Survey Jour. Reseerch, v. 2, no. 3, p. 343-352.

Scholl, D. W., Alphe, T. R., Marlow, M. S., and Buffington, E. C., 1974, Base map of the Aleutian-Bering Sea region: U.S. Geol. Survey Misc. Inv. Map I-879, I sheet, scale 1:2,500,000.

v.s. Bureau of Mines, 1973, Alaska 1/250,000 scale quadrangle map overlays showing mineral deposit locations, princlpal minerals, and number and type of claims: U.S. Bur Mines open-file report OFR 20-73, 153 sheets.

U.S. Geological survey, 1973, Geologtcal survey research 1973: ษ.S. Geol. Survey Prof. Paper 850, 366 p. 
0:S. Geological Survey, 1974, Qualtty of surface waters of the untted States, 1969 - Parts 12-16, North Pacific slope basins, Alaska, Hawa11, and other Paciflc areas: U.S. Geol. Survey Water-Supply Paper 2150, $480 \mathrm{p}$.

Horl, R. G., Van Alstine, R. E., and Heyl, A. V., 1974, Fluorite in the United States (exclusive of Hawa11): U.S. Geol. Survey Mineral Inv. Resources Map MR-60, 13 p., 1 sheet.

\section{OFFSHORE AREAS}

Alpha, T. R., 1974, Bering Sea, orthograpble drawing: U.S. Geol. Survey open-flle map, 1 sheet.

Barues, Peter, Leong, Kar, and Gustafson, Charles, 1974, Map shoring distribution of copper, lead, zinc, mercury, and arsenic in the sediments off the coast of northern Alaska: U.S. Geol. Survey Misc. Fleld Studies Map MF-614, 1 sheet, scale 1:3,375,000.

Carter, cla1re, ed., 1974, Unfted States Geologlcal Survey Alaske Program, 1974: U.S. Geol. Survey C1rc. 700,63 p.

Grantz, Arthur, McHendre, A. G., N1lsen, T. H., and Yorath, C. J., 1974, Selsmic reflection profiles on the continental shelf and slope between Berlng Strait and Barrow, Aleska, and Mackenzle Bay, Canada: U.S. Geol. Survey open-11le rept., 51 sheets.

Grantz, Arthur, McHendrle, A. G., N1lsen, T. H., Yoratb, C. J., and Phillips, J. D., 1974, Digltal magnetic tapes of single channel selsmic reflection proflies on the continental shelf and slope between Bering Strait and Barrow, Alaska, and Mackenzle Bay, Canada: Natl. Tech. Inf. Service PB-232 344, 12 p.

Banne, H. F., Ruppel, D. B., MeBendrle, A. G., and Slkora, R. F., 1974, Residual magnetic anomaly and free-alr gravity anomaly profiles, 1973, on continental shelf and alope between Bering strait and Barrow, Alaska, and Mackenzle Bay, Canada: U.S. Geol. Survey openile report $74-6,6$ sheets.

SeboIl, D. W., Alphe, T. R., Marlov, M. S., and Buffington, E. C., 1974, Base map of the Aleutian-Ber1ng Sea region: U.S. Geol. Survey Misc. Inv. Map I-879, I sbeet, scale I:2,500,000.

U.S. Geological Survey; 1973, Geologtcal survey résearch 1973! U.S. Geol. Survey Prof. Paper 850, 366 p.

Yehle, L. A., 1974, Reconnalssance englneering geology of sitka and vicinity, Alaska, with emphasis on evaluation of earthquake and other geologic hazands: U.S. Geol. Survey open-f1le report. 74-53, $104 \mathrm{p}$. 


\section{ADAK QUADRANGLE}

Alphe, T. R., 1974, Bering Sea, orthographtc drawing: U.S: Geol. Survey open-file map, 1 sheet.

\section{AFOGNAK QUADRANGLE}

Betionan, R. M., 1974, Prellminary geologic map of the southwest quadrant of Aleska: U.S. Geol. Survey Misc. Field Studies Map MF-611, 2 sheets, scale 1:1,000,000.

Mackevett, E. M., Jr., and Plafker, Gec:je, 1974, The Border Ranges fault in south-central Alaska: U.S. Geol. Survey Jour. Research, v. 2, no. 3, p. 323-329.

AMBLER RIVER QUADRANGLE

Alaska Division of Geological and Geophysical Surveys, 2974, Annual Report 1973: Anchorege, Alaska, 59 p.

Bottge, R. G., 1974, Potential mineral resources in selected D.2 lands: U.S. Bur. Mines open-P1le rept. $9-74,55$ p. Also released as Natl. Tech. Inf. Service PB 227 018/As.

\section{AMUKTA QUADRANGLE}

Algha, T. R., 1974, Bering Sea, orthographle drawing: U.S. Geol. Survey open-P1le map, 1 sheet.

\section{ANCHORAGE QUADRANGLE}

Alaska Diviston of Geological and Geophysicel Surveys, 1974, Annuel Report 1973: Anchorage, Alaska, 59 p.

Derbom, L. L., and Freethey, G. H., 1974, Hater-table contour mep, Anchorage area, Alaska: U.S. Geol. Survey open-f1le map, I sheet, scale $1: 24,000$.

Detterman, R. L., Plafker, George, fudson, Travib, Tyadal, R. G., and

- Pavont, Nazar1o, 2974, Surface geology and Holocene breaks along the Susitna segment of the Castle Mountain fault, Alaska: U.S. Geol. Survey M1sc. Fleld Studies Map MF-618, I sheet, scale 1:24,000.

Freethey, G. W., Reeder, J. W., and Barnwell, W. W., 1974, Map showing depth to water, Anchorage area, Alaska: U.S. Geol. Survey openrile map, 1 sheet, scale 1:24,000. 


\section{ANCHORAGE QUADRANGLE}

Barkfna, D. B., 1973, Sedimentary zeolite deposits of the upper Matanuske Valley, Alaska! Ala'ska Diy. Geol. Geophys. Surveys Spec. Rept. 6, 17 p.

Labr, J. C., Page, R. A., and Thomas, J. A., 1974, Catalog of earthquakes in south central Alaska, April-June 1972: U.S. Geol. Survey open-11le report, $35 \mathrm{p}$.

Mackevett, E. M., Jr., and Plafker, George, 1974, The Border Ranges fault in south-central Alaska: U.S. Geol. Survey Jour. Research, v. 2, no. 3, p. 323-329.

schmoll, R. R., and Dobrovolny, Enest, 1974, Constmetion materials map of Ancharage and vicinity, Alaska: U.S. Geol. Survey Misc. Geol. Inv. Map I-787-C, i sheet, scale 1:24,000.

Schmoll, H. R., and Dobrovolny, Ernest, 1974, Foundation and excavation conditions map of Anchorage and vicinity, Alaska: U.S. Geol. Survey Misc. Geol. Inv. Map I-787-D, 1 sheet, scale 1:24,000.

U.8. Geological Survey, 1973, Geological survey résearch 1973! U.S. Geol. Survey Prof. Paper 850, $366 \mathrm{p}$.

zenone, Chester, and Donaldson, D. E., 1974, Water-quelity and geohydrologic data at two sanitary landfill sites near Anchorage, Alaska: U.S. Geol. Survey open-file report, 1 sheet.

Zenone, Chester, Schmoll, H. R., and Dobrovolny, Ernest, 1974, Geology and ground water for land use planning in the Eagle River-Chugiak area, Aloska: U.S. Geol. Survey open-flle report $74-57,36$ p.

\section{ATKA QUADRANGLE}

Alpha, T. R., 1974, Berling Sea, orthographic drawling: U.S. Geol. Survey open-flle map, 1 sheet.

\section{ATIU QUADRANGLE}

Alpha, T. Ri, 1974, Bering Sea, orthographic aranting: U.S. Geol. Survey open-r1le map, 1 sheet. 


\section{BAIRD INLET QUADRANGLE}

Alpha, T. R., 1974, Bering Sea, orthographle draslag! U.S. Ceol. Survey open-file map, 1 sheet.

Belkman, H. M., 1974, Preliminary geologic map of the southwest quadrant of Alaska: U.S. Geol. Survey Misc. Fleld Studies Map MF-6II, 2 sheets, scale $1: 1,000,000$.

Bottge, R. G., 1974, Potential mineral resources in selected D.2 lands: U.S. Bur. Mines open-file rept. 9-74, 55 p. Also relessed as Natl. Tech. Inf. Service PB 227 Ol8/AS.

\section{BAIRD MOUNTATNS QUADRANGLE}

Alaska Dlvision of Geologlcal and Geophysical Surveys, 1974, Annual Report 1973: Anchorage, Alaska, 59 p.

U.8. Geologleal survey, 1973, Geological survey research 1973: U.S. Geol. Survey prot. Paper 850, 366 p.

\section{BARROW QUADRANGLE}

Grantz, Arthur, Mchendrle, A. G., Nilsen, T. B., and Yorath, C. J., 1974, Selomic reflection proflles on the continental shelf and slope between Bering Strait and Barrow, Alaska, and Mackenzie Baj, Canada: U.S. Geol. Survey open-f1le rept., 51 sheets.

Grantz, Arthur, Mchendrle, A.G., Nilsen, T. H., Yorath, C. J., and Phillips, J. D., 1974, Digital megnetic tapes of single channel selsmic reflection profiles on the continental shelf and slope between Bering Strait and Barrow, Alaska, and Mackenzie Bay, Canada: Natl. Tech. Inf. Serv1ce PB-232 344, 12 p.

Hanna, W. F., Ruppel, D. B., MCRendrle, A. G., and Stkora, R. F., 1974, Residual magnetic anomaly and free-alr gravity anomaly propileo, 1973, on continental shelf and slope between Bering stralt and Barrow, Alaska, and Mackenzle Bay, Canada: U.S. Geol. Survey openflle report $74-6,6$ sheets.

v.8. Geological Survey, 1973, Geological survey research 1973: U.S. Geol. Survey Prof. Paper 850, 366 p. 


\section{BARTER ISLAND QUADRANGLE}

Barnes, Peter, Leong, Kam, and Gustafson, Charles, 1974, Map shoulng distribution of copper, lead, zinc, mercury, and arsentc in the sediments off the coast of northern Alaska: U.S. Geol. Survey Mac. Fleld Studies Map MF-614, I sheet, scale 1:3,375,000.

Grantz, Arthur, McHendrie, A. G., Nilsen, 1. H., and Yorath, C. J., 2974, Seismic reflection profiles on the continental shelf and slope between Bering Stra1t and Barrow, Alaske, and Mackenzle Bay, Canade: U.S. Geol. Survey open-flle rept., 51 sheets.

Grantz, Arthur, McHendrie, A. G., Nilsen, T. H., Yorath, C. J., and Phlllips, J. D., 1974, Digltal magnetlc tapes of single channel selsmic reflection profiles on the continental sheif and slope between Bering Strait and Barrow, Alaska, and MacKenzle Bay, Canada: Natl. Tech. Inf. Service PB-232 344,12 p.

Banne, H. F., Ruppel, D. B., MeHendrte, A. G., and stkora, R. F., 1974, Residual magnetic anomaly and free-air gravity anomaly profiles, 2973, on continental shelf and slope between Bering stralt and Berrow, Alaska, and Mackenzle Bay, Canada: U.S. Geol. Survey openfile report $74-6,6$ sheets.

\section{BEAVER QUADRANGLE}

Bottge, R. G., 1974, Potential mineral resources in selected D.2 lands: U.S. Bur. Mines open-file rept. 9-74, 55 p. Also released as Nat1. Tech. Inf. Service PB 227 018/AS.

Carter, Claire, ed., 1974, United States Geological Survey Alaska Program, 1974: U.S. Geol. Survey C1re. 700, 63 p.

Milligan, J.J., 1974, Mneral resources of the trans-Alaska pipeline corridor: U.S. Bur. Mines Inf. C1rc. 8626, 24 p.

1.8. Geologlcal Survey, 1973, Geological Survey résearch 1973: U.S. Geol. Survey Prof. Paper 850,366 p.

0.8. Ceological Survey, 1974, Aeromagnetic map of eastern half of the Beever quadrangle, northeastern Alaska! U.S. Geol. Survey open-f1le map, 1 sheet, scale 1:250,000.

ti.s. Geological survey, 1974, Aeromegnetic map of eastern half of the Beaver quadrangle, northeastem Alaske: U.S. Geol. Survey open-file map, 12 sheets, scale 1:63,360. 
Bernes, Peter, Leong, Kam, and Gustafson, Charles, 1974, Map showing distribution of copper, lead, zine, mercury, and arsenic in the sediments of the coast of northern Alaska: U.S. Geol. Survey
Misc. Field Studies Map MF-6I4, I sheet, scale 1:3,375,000.

Chtlders, J. M., 1974, Flood surveys along TAPS route, Alaska: U.S. Geol. Survey open-file report, $16 \mathrm{p}$.

Detterman, R. I., 3974, Fence diagram showing lithologic facies of the Sadierochit Formation (Permian and lower Priassic), northeastern Alaska: U.S. Geol. Survey Misc. Field Studies Map MF-584, 1 sheet.

Grantz, Arthur, MeHeudrie, A. G., Nilsen, T. H., and Yorath, C. J., 1974, Selsmic reflection profiles on the continental shelf and slope between Bering Strait and Barrow, Alaska, and Mackenzle Bay, Canada: U.S. Geol. Survey open-flle rept., 51 sheets.

Grantz, Arthur, McHendrie, A. G., Nilsen, T. H., Yorath, C. J., and Phillips, J. D., 1974, Digital magnetic tapes of single channel seismic reflection profiles on the continental shelf and slope between Bering Strait and Barrow, Alaska, and Mackenzle Bay, Canada: Natl. Tech. Inf. Service PB-232 344, 12 p.

Hanna, H. F., Ruppel, D. B., Mchendrie, A. G., and Stkora, R. F., 1974, - Resloual magnetic anomaly and free-air gravity anomaly profiles, 1973, on continental shelf and slope between Bering stralt and Barrow, Alaska, and MacKenzie Bay, Canada: U.S. Geol. Survey openrile report $74-6,6$ sheets.

Mulligan, J. J., 2974, Mineral resources of the trans-Alaska pipeline corridor: U.S. Bur. Mines Inf. C1rc. 8626, 24 p.

Nauman, J. W., and Kernodle, D. R., 1974, Aquatte organtsms from selected sites along the proposed trans-Alaska pipeline corridor, September 1970 to September 1972: U.S. Geol. Survey open-f1le report, 23 p.

U.8. Ceological survey, 1973, Geological survey research 1973: U.S. Geol. Survey Prof. Paper 850, 366 p. 
Alaska Division of Geological and Geophysical Surveys, 1974, Annual Report 1973: Anchorage, Alaska, 59 p.

Bottge, R. G., 1974, Potential mineral resources in selected D. $\hat{c}$ lands: U.S. Bur. Mines open-f1le rept. 9-74, 55 p. Also released as Natl. Tech. Inf. Service PB $227018 / \mathrm{AS}$.

Carter, Claire, ed., 1974, United States Geological Survey Alaska Program, 1974: U.S. Geol. Survey Circ. 700, 63 p.

Johnson, G. R., and Sainsbury, C. L., 1974, Aeromagnetic and generallzed geologlc map of the west-central part of the Sewerd Peninsula, Alaska: U.S. Geol. Survey Geophys. Inv. Map GP-881, 1 sheet, scale $1: 125,000$.

Marvin, R. F., 1974, A tabulation of K-Ar, Rb-Sr, and Pb-a ages obtalned From materials within the United States (Including Alaska and Hawail) during the years 1969 through 1971: U.S. Geol. Survey open-f1le report, $193 \mathrm{p}$.

U.S. Geological survey, 1973, Geological survey research 1973: U.S. Geol. Survey Prof. Paper 850, 366 p.

\section{BERING GLACIER QUADRANGLE}

Bottge, R. G., 1974, Potential mineral resources in selected D. $\hat{2}$ lands: U.S. Bur. Mines open-file rept. 9-74, 55 p. Also released as Nat1. Tech. Inf. Service PB $227018 / A S$.

Carter, Cla1re, ed., 1974, United States Geological Survey Alaska Program, 1974: U.S. Geol.' Survey C1re. 700, 63 p.

Mackevett, E. M., Jy., and Plafker, George, 1974, The Border Ranges fault in south-central Alaska: U.S. Geol. Survey Jour. Research, v. 2, no. 3, p. $323-329$.

\section{BLWIILL QUADRANGLE}

Alaska Division of Geological and Geophysical Surveys, 1974, Arnual Report 1973: Anchorage, Alaska, 59 p.

Belkman, H. M., 1974, Preliminary geologic map of the southwest quedrant of Alaska: U.S. Geol. Survey Misc. Field Studies Map MF-611, 2 sheets, scale $1: 1,000,000$.

Carter, Clalre, ed., 1974, United States Geological Survey Alsska Program, 1974: U.S. Geol. Survey C1rc. 700, 63 p. 
Bottge, R. G., 1974, Potential mineral resources in selected D.2 lands: U.S. Bur. Mines open-f1le rept. 9-74, 55 p. Also released as Natl. Tech. Inf. Service PB 227 018/AS.

Carter, Cla1re, ed., 1974, United States Geological Survey Alaska Program, 1974: U.S. Geol. Survey c1rc. 700,63 p.

Childers, J. M., 1974, Flood surveys along TAFS route; Alaska: U.S. ceol. Survey open-file report, $16 \mathrm{p}$.

Marvin, R. F., 1974, A tabulation of K-Ar, Rb-Sr, and Pb-a ages obtalned from materials within the Unjted States (1acluding Alaska and Hawai1) during the years 1969 through 1971: U.S. Geol. Survey open-11le report, $193 \mathrm{p}$.

Mulligan, J. J., 1974, Mineral resources of the trans-Alaska plpeline corr1dor: U.S. Bur. Mines Inf. C1rc. 8626, 24 p.

Nauman, J. W., and Kernodle, D. R., 1974, Aquatle organlsms from selected sites along the proposed trans-Alaske plpeline corridor, September 1970 to September 1972: U.S. Geol. Surves open-f1le report, $23 \mathrm{p}$.

0.8. Ceological survey, 1973, Geologlcal survey reacarch 1973: U.S. Geol. Survey Prof. Paper 850, 366 p.

\section{BIG DELTA QUADRANGLE}

Chllders, J. M., 1974, Flood surveys along TAPS route, Alaska: U.S. Geol. Survey open-file report, $16 \mathrm{p.}$

Mulligan, J.J., 1974, Mineral resources of the trans-Alaske plpeilne corrldor: U.S. Bur. Mines Inf. C1rc. 8626, 24 p.

Rauman, J. W., and Kernodle, D. R., 1974, Aquatic organlsins from selected sites along the proposed trans-Alaska pipeline corridor, September 1970 to September 1972: U.S. Geol. Survey open-f1le report, 23 p.

\section{BLACK QUADRANGLE}

Alpha, T. R., 1974, Berlng Sea, orthographle drawing: U.S. Geol. Survey open-P1le map, 1 sheet.

Belkman, H. M., 1974, Prellminary geologic map of the southwest quadrant of Aleska: U.S. Geol. Survey Misc. Field studies Map MF-6I1, 2 sbeets, scale 1:1,000,000. 


\section{BRADFIELD CANAL QUADRAHGLE}

Alaske Division of Geological and Geophysical Surveys, 1974, Annual Report 1973: Anchorage, Alaska, 59 p.

Berg, B. C., and others, 1974, Magnet1c tape containing spectrographtc and chemical analyses of rock and stream-sediment semples from the Grantte Flords Wildemess Study Area, Alaska: Natl. Tech. Inf. Service PB-232 049, magnetic tipe.

Carter, claire, ed., 197.4, United States Geological survey Alagke Program, 1974: U.S. Geol. Survey Cire. 700, 63 p.

\section{BRTSIOL BAY QUADRANGLE}

Belkman, H. M., 1974, prellminary geologic map of the southwest quadrant of Alaska: U.S. Geol. Survey Misc. Field Studies Map MF-61I, 2 sbeets, scale $1: 1,000,000$.

\section{CANDLE QUADRANGLE}

Marvin; R. F., 1974, A tabulation of K-Ar, Rb-Sr, and Pb-c ages obtatned from materials within the United States (Including Alaska and Hawa11) during the years 1965 through 1968: U.S. Geol. Survey open-file report, $245 \mathrm{p}$.

\section{CAPE MENDENHALL QUADRANGLE}

Alpha, T. R., 1974, Bering Sea, orthographle drawing: U.S. Geol. Survey open-file map, I sheet.

Beikman, H. M., 1974, Preliminary geologlc mep of the southwest quadrant of Alaska: U.S. Geol. Survey Misc. Fleld Studies Map MF-61l, 2 sheets, Bcale 1:1,000,000. 


\section{CRANDALAR QUADRANGTE}

Alaska Diviston of Geological and Geophysical Surveys, 1974, Annual Report 1973: Anchorage, Alaska, $59 \mathrm{p}$.

Bottge, R. G., 1974, Potential mineral resources in selected $0 . \hat{2}$ lands: U.S. Bur. Mines open-P1le rept. 9-74, 55 p. Also released as Natl. Tech. Inf. Service PB $227018 / A S$.

ChIlders, J. M., 1974, Flood surveys along TAPS route, Alaska: U.S. ceol. Survey open-file report, $16 \mathrm{p}$.

Muligan, J. J., 1974, Mineral resources of the trans-Alosks plpeline corridor: U.S. Bur. Mines Inf. C1re. 8626, 24 p.

Nauman, J. W., and Kemodle, D. R., 1974, Aquatlc organisms from selected sites along the proposed trans-Alaska plpeline corridor, September 1970 to September 1972: U.S. Geol. Survey open-f1le report, $23 \mathrm{p}$.

0.8. Geological survey, 1974, Aeromegnet1c map of eastern haif of the Chandalar quadrangle, northeastern Alaska: U.S. Geol. Survey openfile map, I sheet, scale 1:250,000.

U.5. Geolog1cal Survey, 1974, Aeromagnetic map of eastem half of the Chandalar quadrangle, northeastern Alaska: U.S. Geol. Survey openfile map, 12 sheets, scale $1: 63,360$.

\section{CHANDLER LAKE QUADRANGLE}

Bottge, R. G., 1974, Potent1al mineral resources in selected D.2 lands: U.S. Bur. Mines open-file rept. 9-74, 55 p. Also released as Natl. Tech. Inf. Service PB 227 018/As.

\section{CHARLEY RIVER QUADRANGLE}

Alaska Division of Geological and Geophysical Surveys, 1974, Annual Report 1973: Anchorage, Alaska, 59 p.

Bottge, R. G., 1974, potential mineral resources in selected D.2 lands: U.S. Bur. Mines open-P1le rept. 9-74, 55 p. Also released as Natl. Tech. Inf. Service PB 227 018/AS.

\section{CHIGNTK QUADRANGLE}

Alaska Division of Geological and Geophysical Surveys, 1974, Annual Report 1973: Anchorage, Alaska, 59 p. 


\section{CHRISTIAN QUADRANGLE}

v.S. Ceological survey, 1973, Geological survey research 19个3!

U.S. Geol. Survey Prof. Paper 850, 366 p.

\section{CIRCLE QUADRANCLE}

Bottge, R. G., 2974, Potential mineral resources in selected D.2 lands: U.S. Bur. Mines open-fille rept. 9-74, 55 p. Also released as Natl. Tech. Inf. Service PB 227 018/AS.

Marvin, R. F., 1974, A tabulation of K-Ar, Rb-Sr, and Pb-a ages obtalned from materials within the United States (Including Alaska and Bawal1) during the years 1956 through 1964: U.S. Geol. Survey open-file report, $174 \mathrm{p}$.

U.S. Geological Survey, $197^{4}$, Aeromagnet1c map of the circle quadrangle, northeastern Alaska: U.S. Geol. Survey open-f1le map, I sheet, scale 1:250,000.

U.S. Ceological Survey, 1974, Aeromagnet1c map of the chrcle quadrangle, northeastern Alaska: U.S. Geol. Survey open-f1le map, 24 sheets, bcale 1:63,360.

\section{CORDOVA QUADRANGLE}

Carter, Cla1re, ed., 1974, United States Geologlcal Survey Alaska Program, 1974: U.S. Geol. Survey C1re. 700, 63 p.

Lahr, J. C., Page, R. A., and Thomas, J.A., 1974, Catalog of earthquakes in south central Alaska, Aprll-June 1972: U.S. Geol. Survey open-flle report, $35 \mathrm{p}$.

Mligan, J.J., 1974, Mineral resources of the trans-Alaska pipeline corridor: U.S. Bur. Mines Inf. C1rc. 8626, $24 \mathrm{p}$.

Plafker, George, 1974, Prellminary geologle map of Kayak and Wingham Islands, Alaska: U.S. Geol. Survey open-flle map 74-82, 1 sheet, scale 1:31,680.

U.9. Geological Survey, 1973, Geologlcal Survey research 1973: U.S. Geol. Survey Prot. Paper 850,366 p. 


\section{CRAIG QUADRANGLE}

Alaske Division of Geological and Geophysical Surveys, 1974, Annual Report 1973: Anchorage, Alaska, 59 p.

carter, clatre, ed., 1974, United states Geological Survey Alaska Program, 1974: U.S. Geol. Survey Cire. 700, 63 p.

Herreld, Gordon, and Trible, T. C., 1973, Analyses of stream sediment samples, Craig A-2 quadrangle and viclnity, Prince of Weles Island, southeastern Alaska! Alaska Div. Geol. Geophys. Surveys Geochem. Rept. 27, 5 sheets.

Marvin, R. F., 1974, A tabulation of K-Ar, Rb-Sr, and Pb-r ages obtalned from materials within the United States' (1ncluding Alaska and Bawai1) during the years, 1956 through 1964: U.S. Geol. Survey open-file report, $174 \mathrm{p}$.

U.8. Geological survey, 1973, Geological survey research 1973: U.S. Geol. Survey Prop. Paper 850,366 p.

DE LONG MOUNTAINS QUADRANGLE

Carter, Cla1re, ed., 1974, United States Geological Survey Alaska Program, 1974: U.S. Geol. Survey C1rc. 700, 63 p.

\section{DEMARCATION POINT QUADRANGLE}

Carter, cla1re, ed., 1974, United States Geologlcal Survey Alaska Program, 1974: U.S. Geol. Survey Circ. 700, 63 p.

Detterman, R. I., 1974, Fence diagram showing l1thologlc facies of the Sadlerochit Formation (Permian and lower Triasslc), northeastern Alaska: U.S. Geol. Survey Misc. Field Studies Map MF-584,

Grantz, Arthur, Mckendrie, A. G., Nilsen, T. H., and Yorath, C. J., 1974, Selsmic reflection profiles on the continental shelf and slope between Bering Strait and Barrow, Alaska, and Mackenzle Bay, Canada: U.S. Geol. Survey open-file rept., 51 sheets.

Grantz, Arthur, McHendrie, A. G., Nilsen, T. H., Yorath, C. J., and Phillips, J. D., 1974, Digital maguetic tapes of single channel selsmic reflection profiles on the continental shelf and slope between Bering Strait and Barrow, Alaska, and Mackenzie Bay, Cansia: Natl. Tech. Inf. Service PB-232 344, 12 p.

Relser, E. N., Brosgé, H. P., Dutro, J. T., JY., and Detteman, R. L., 1974, Preliminary geologlc map of the Demarcation Polnt quadrangle, Alaska: U.S. Geol. Survey Misc. Fleld Studies Map MF- 610, I sheet, scale $1: 200,000$.

U.S. Geological Survey, 1973, Geological survey research 1973! U.S. Geol. Survey Prof. Paper 850,366 p. 


\section{DILEINGHAM QUADRANCLE}

Betkman, H. M., 1974, Prellminary geologic map of the southwest quadrant of Aleska: U.S. Geol. Survey Misc. Fleld Studies Map MF-6II, 2 sheets, scale $1: 1,000,000$.

Dettermen, R. I., and Reed, B. L., 1973, Surficial deposits of the Illamna quadrangle, Alaska: U.S. Geoit. Survey Bull. 1368-A, p. AIA64.

\section{DIXON ENIRANCE QUADRANGLE}

Herrold, Gordon, and Trible, T. C., 1973, Analyses of stream sediment samples, Croig A-2 quadrangle and vicinity, Prince of Wales Island, southeestern Alaska: Alaska Div. Geol. Geophys. Surveys Geochem. Rept. 27, 5 sheets.

U.S. Geological survey, 1973, Geological survey research 1973: U.S. Geol. Survey Prof. Papar 850, 366 p.

Worl, R. G., Van Alstine, R. E., and Reyl, A. V., 1974, Fluorite in the United States (exclusive of Hawa11): U.S. Geol. Survey Mineral Inv. Resources Map MR-60, 13 p., I'sheet.

\section{EAGLE QUADRANGLE}

Aleska Division of Geological and Geophysical Surveys, 1974, Annual Report 1973: Anchorage, Alaska, 59 p.

Carter, Cla1ré, ed., 1974, United States Geologleal Survey Alaska Program, 1974: U.S. Geol. Survey C1re. 700, 63 p.

Foster, H. L., and Kelth, T. E. C., 1974, Ultramafic rocks of the Eagle quadrangle, esst-central Alaska! U.S. Geol. Survey Jour. Research, v. 2, no. 6, p. 657-669.

Marvin, R. F., 1974, A tabulation of K-Ar, Rb-Sr, and Pb-x ages obtalned from materials within the United States (including Alaske and Hawai1) during the years 1956 through 1964: U.S. Geol. Survey open-f1le report, 174 p.

U.S. Geological survey, 1973, Goological survey research 1973! U.S. Geol. Survey Prof. Paper 850, $366 \mathrm{p}$.

WorI, R. G., Van Alstine, R. E., and Hey1, A. V., 1974, Fluortte in the United States (exclusive of Hawa11): U.S. Geol. Survey Mineral Inv: Resources Map MR-60, 13 p., 1 sheet. 
Alaske Division of Geological and Geophyalcal Surveys, 1974, Annual Report 1973: Anchorage, Alaska, 59 p.

Carter, Claire, ed., 1974, United States Ceolog1cal Survey Alaska Program, 1974: U.S. Geol. Survey C1rc. 700, 63 p.

Marvin, R. F., 1974, A tabulation of $\mathrm{K}-\mathrm{Ar}, \mathrm{Rb}-\mathrm{Sr}$, and $\mathrm{Pb}-x$ ages obtalned Prom materials within the United Statea (Including Alaska and Hawa11) during the years 1956 through 1964: U.S. Geol. Survey open-file report, $174 \mathrm{p}$.

Marvin, R. F., 1974, A tabulation of K-Ar, Rb-Sr, and Pb-ceges obtelned from materials within the United States (Including Alaska and Hawa11) during the years 1969 through 1971: U.S. Geol. Survey open-f1le report, $193 \mathrm{p}$.

Malligan, J. J., 1974, Mineral resources of the trans-Alaska plpellne corridor: U.S. Bur. Mines Inf. C1re. 8626, 24 p.

Vauran, J. W., and Kernodle, D. R., 1974, Aquatic organisms from seleem ted sites along the proposed trans-Aleska plpeline corrldor, September 1970 to September 1972: U.S. Geol. Survey open-f1le report, $23 \mathrm{p}$.

\section{FALSE PASS QUADRANGLE}

Wore, J. C., 1974, Geologic and structural map of the Samak Islands, southwestern Alaska: U.S. Geol. Survey Misc. Geol. Inv. Map I-817, 1 sheet, scsle $1: 63,360$.

\section{FLAXMAN ISLAND QUADRANGLE}

Barmes, Peter, Leong, Kam, and Gustafson, Charles, 1974, Map showing distribution of copper, lead, 2inc, mercury, and arsentc in the sediments off the coast of northern Alaska: U.S. Geol. Survey M1sc. Fleld Studies Map MF-614, 1 sheet, scale 1:3,375,000.

Grantz, Arthur, McHendrle, A. G., Ntlsen, T.: H., and Yorath, C. J., 1974, Seismic reflection profiles on the continental shelf and . slope between Bering Strait and Barrow, Alaska, and Mackenzle Bay, Canada: U.S. Geol. Survey open-f1le rept., 51 sheets.

Grantz, Arthur, MeHendrie, A. G., N11sen, T. H., Yorath, C. J., and Phtllips, J. D., 1974, Digltal magnet1c tapes of single channel selsmic reflection profiles on the continentel shelf and slope between Bering Strait and Barrow, Alaska, and MacKenzle Bay, Canada: Natl. Tech. Inf. Service PB-232-344, 12 p.

Banna, H. F., Ruppel, D. B., McHendrte, A. G., and s1kore, R. F., 1974, Residual magnetic anomaly and free-alr gravity anomaly profiles, 1973, on continental shelf and slope between Berling Stralt and Barrow, Alaska, end MacKenzie Baỳ, Canada: U.S. Geol. Survey openpile report: $74-6,6$ sbeets. 


\section{GARETOI ISLAND QUADRANGLE}

Alpha, T. R., 1974, Bering Sea, orthographle drawing! U.S. Geol. Survey open-file map, I sheet.

\section{GOODNEWS QUADRANGLE}

Belkmar, H. M., 1974; Preliminary geologie map of the southwest quadrant of Alaska: U.S. Geol. Survey Misc. Fleld Studies Map MF-611, 2 sheets, scale 1:1,000,000.

Carter, Cle1re, ed., 1974, United States Geological survey Alaska Program, 1974: U.S. Geol. Survey clrc. 700, 63 p.

\section{GUIKANA QUADRANGLE}

Alaske Division of Ceological and Geophysical Surveys, 1974, Annual Report 1973: Anchorage, Alaska, 59 p.

Carter, cla1re, ed., 1974, United States Geologlcal survey Alaska Program, 1974: U.S. Geol. Survey C1re. 700, 63 p.

Marvin, R. F., 1974, A tabulation of K-Ar, Rb-Sr, and Pb-re ages obtalned from materials within the infted States (Including Alaske and Hawal1) during the years 1965 through 1968: U.S. Geol. Survey open-file report, $245 \mathrm{p}$.

Mulligan, J.J., 3974, Mineral resources of the trans-Alaske plpeline corridor: U.S. Bur. Mines Inf. C1rc. 8626, 24 p.

Nauman, J. W., and Kernodle, D. R., 1974, Aquatic organisms from sellected sites along the proposed trans-Alaska pipeline corridor, September 1970 to September 1972: U.S. Geol. Survey open-file report, 23 p.

\section{HAGEMEISTER ISLAND QUADRANGLE}

Alaska Division of Geological and Geophyslcal Surveys, 1974, Annuel Report 1973: Anchorage, Alaska, 59 p.

Belkman, H. M., 1974, Preliminary geologic map of the southwest quadrant of Alaska: U.S. Geol. Survey M1sc. Fleld Studies Map MF-6Il, 2 sheets, scele 1:1,000,000.

Carter, claire, ed., 1974, United States ceological. Survey Alaska Program, 1974: U.S. Geol. Survey C1re. 700, 63 p.

U.S. Geological survey, 1973, Geological survey résearch 1973: U.S. Geol. Survey Prof. Paper 850, 366 p. 
Barnes, Peter, Leong, Kam, and Gustafson, Charles, 1974, Map showing distribution of copper, lead, zinc, mercury, and arsente in the sediments off the coast of northern Alaska: U.S. Geol. Survey M1sc. Field Studies Map MF-614, 1 sheet, scale 1:3,375,000.

Granti, Arthur, Mchendrie, A. G., N1lsen, T. H., and Yorath, C. J., 1974,: Selsmic reflection profiles on the continentel shelf and slope between Bering Strait and Barrow, Alaska, and Mackenzle Bay, Canada: U.S. Geol. Survey open-file rept., 51 sheets.

Crantz, Arthur, McHendrie, A. G., Nilsen, T. B., Yorath, C. J., and PhIllips, J. D., 1974, Digital magnetic tapes of single channel selsmic replection profiles on the continental sheif and slope between Bering Strait and Barros, Alaske, and Mackenzie Bay,

Canada: Natl. Tech. Inf. Service PB-232 344, 12 p.

Hanna, W. F., Ruppel, D. B., Mchendrle, A. G., and Sikora, R. F., 1974, Residual magnetic anomaly and free-alr gravity anomaly profiles, 1973, on continental shelf and slope between Bering stralt and Barrow, Alaska, and Mackenzie Bay, Canada: U.S. Geol. Survey openpile report $74-6,6$ sheets.

\section{HEALY QUADRANGZE}

Alaska Division of Ceological and Geophysical Surveys, 1974, Anmual Report 1973: Anchorage, Alaska, 59 p.

Marvin, R. F., 1974, A tabulation of K-Ar, $\mathrm{Rb}-\mathrm{Sr}$, and Pb-ai ages obtained from materials within the United States (including Alaske and Hawa11) during the years 1969 through 1971: U.S. Geol. Survey open-f1le report, $193 \mathrm{p}$.

U.S. Geological Survey, 1973, Geological survey research 1973! U.S. Geol. Survey Prof, Paper 850, 366 p.

\section{HOLY CAOSS QUADRANGLE}

Belkmen, H. M., 1974, Prellminary geologle map of the southwest quadrant of Alaska: U.S. Ceol. Survey Misc. Fleld Studies Map MF-6II, ?2 sheets, scale $1: 1,000,000$.

\section{HOOPER BAY QUADRANGLE}

Alphe, T. R., 1974, Bering Sea, orthographle drawing: U.S. Ceol. Survey open-f1le map, I sheet.

Belkman, H. M., 1974, Prellmimary geologic map of the southwest quadrant of Alaska: U.S. Geol. Survey Misc. Fleld Studies Map MF-6ll, 2 sheets, scale $1: 1,000,000$. 


\section{HUGHES QUADRANGLE}

Alaske Division of Geological and Geophysical Surveys, 1974, Annual Report 1973: Anchorage, Alaska, $59 \mathrm{p}$.

Marvin, R. F., 1974, A tabulation of $\mathrm{K}-\mathrm{Ar}, \mathrm{Rb}-\mathrm{Sr}$, and $\mathrm{Pb}-\mathrm{r}$ ages obtained Prom materials within the United States (Including Alaska and Hawa11) during the years 1965 through 1968: U.S. Geol. Survey open-flle report, $245 \mathrm{p}$.

\section{IDITAKOD QUADRANGLE}

Alaska Dlvision of Geological and Geophysical Surveys, 1974, Annual Report 1973: Ancho:age, Alaska, 59 p.

Belkman, H. M., 1974, Preliminary geologte map of the southwest quadrant of Alaska: U.S. Geol. Survey Misc. Fleld Stuales Map MF-61l, 2 sheets, scale $1: 1,000,000$.

Marvin, R. F., 1974, A tabulation of K-Ar, Ro-Sr, and Pb-x ages obtained Prom materials within the United States (including Alaska and Hawa11) during the years 1956 through 1964: U.S. Geol. Survey open-file report, $174 \mathrm{p}$.

\section{IKPIKSUK RIVER QUADRANGLE}

Bottge, R. G., 1974, Potential mineral resources in selected D.2 lands: U.S. Bur. Mines open-file rept. $9-74,55$ p. Also released as Natl. Tech. Inf. Service PB 227 018/AS.

\section{ILIANA QUADRANGLE}

Beikman, R. M., 1974, Preliminary geologlc map of the southwest quadrant of Alaska: U.S. Geol. Survey Misc. Fleld Studies Map MF-61I, 2 sheets, scale $1: 1,000,000$.

Bottge, R. G., 1974, Potential mineral resources in selected D.2 lands: U.S. Bur. Mines open-f1le rept. 9-74, 55 p. Also released as Natl. Tech. Inf. Service PB 227 018/AS.

Dettermen, R. L., 1973, Geologic map of the Iliamne B-2 guadrangle, Augustine Island, Alaska: U.S. Geol. Survey Geol. Quad. Map CQ-1068, I sheet, scale $1 ; 63,360$.

Detterman, R. L., and Reed, B. L., 1973, Surficial deposits of the Iltamna quadrangle, Alaska: U.S. Geol. Survey Bull. 1368-A, p. AlA64.

Lahr, J. C., Page, R. A., and Thomas, J. A., 1974, Catalog of earthquakes in south central, Alaska, April-June 1972: U.S. Geol. Survey open-pile report, $35 \mathrm{p}$. 
Nerv1n, R. F., 1974, A tabulation of K-Ar, Rb-Sr, and Pb-ce ages obtalned Prom materials within the United States (Including Alaska and Hawai1) during the years 1965 through 1968: U.S. Geol. Survey open-fille report, $245 \mathrm{p}$.

Marvin, R. F., 1974, A tabulation of K-Ar, Rb-Sr, and Pb-a= ages obtained from materials within the United States (1ncluding Alaska and Hawai1) during the years 1969 through 1971: U.S. Geol. Survey open-11le report, $193 \mathrm{p}$.

U.8. Geological survey, 1973, Geological survey research 1973: U.S. Geol. Survey Prof. Paper 850, 366 p.

\section{JUNEAU QUADRANGLE}

Carter, claire, ed., 1974, United States Geological Survey Alaska Program, 1974: U.S. Geol. Survey Cire. 700, 63 p.

Marvin, R. F., 1974, A tabulation of K-Ar, Rb-Sr, and Pb-c ages obtalned from materlals within the United States (Including Alaska and Hawa11) during the years 1965 through 1968: U.S. Geol. Survey open-11le report, $245 \mathrm{p}$.

Marotn, F. F., 1974, A tabulation of $\mathrm{K}-\mathrm{Ar}, \mathrm{Rb}-\mathrm{Sr}$, and Pb-a ages obtalned from materials within the United States (Including Alaska and Hawail) durlng the years 1969 through 1971: U.S. Geol. Survey open-P1le report, $193 \mathrm{p}$.

\section{KANTISHNA RIVER QUADRANGLE}

Belkman; H. M., 1974, Preliminary geologic map of the soutbwest quadrant of Alaska: U.S. Geol. Survey Misc. Field Studies Map MF-611, 2 sheets, scale $1: 1,000,000$.

\section{RARLUK QUADRANGLE}

Belkman, R. M., 1974, Preliminary geologic map of the southwest quad. rant of Alaska: U.S. Geol. Survey Misc. Fleld Studies Map MF-617, 2 sheets, scale $1: 1,000,000$.

Mackevett, E. M., Jr., and Plafker, George, 1974, The Border Ranges fault in south-central Alaska! U.S. Geol. Survey Jour. Research, v. 2, no. 3, p. 323-329. 


\section{KENAT QUADDRANGLE}

Beliman, H. M., 1974, Preliminary geologic mep of the southwest quadrant of Alaska: U.S. Geol. Survey Misc. Field Studies Map MF-61l, 2 sheets, scale $1: 1,000,000$.

Blasko, D. P., 1974, Natural gas Plelds -- Cook Inlet basin, Alaska: U.S. Bur. Mines open-file report $35-74,24$ p. Also released as Net1. Tech. Inf. Service PB 235 767-AS.

Carter, Claire, ed., 1974, United states Geological survey Alaska Program, 2974: U.S. Geol. Survey Circ, 700, 63 p.

Detterman, R. L., and Reed, B. L., 1973, Surficlel deposits of the Iliemna quadrangle, Alaska: U.S. Geot. Survey Bull. 1368-A, p. AlA64.

Labr, J. C., Page, R. A., and Thomas, J. A., 1974, Catalog of earthquakes in south central Alaska, April-June 1972: U.S. Geol. Survey open-file report, $35 \mathrm{p}$.

Mackevett, E. M., Jx., and Plafker, George, 1974, The Border Ranges fault in south-central Alaska: U.S. Geol. Survey Jour. Research, v. 2, no. 3, p. 323-329.

Mervin, R. F., 1974, A tabulation of X-Ar, Rb-Sr, and Pb-r ages obtained Prom materials within the United States (Including Alaska and Hawati) during the years 1965 through 1968: U.S. Geol. Survey open-I1le report, $245 \mathrm{p}$.

Marvin, R. F., 1974, A tabulation of K-Ar, Rb-Sr, and Pb-e ages obtalned from materials within the United States (including Alaska and Hawai1) during the years 1969 through 1971: U.S. Geol. Survey open-f1le report, $193 \mathrm{p}$.

Reed, B. L., and Lanphere, M. A., 1974, Chemical vartations across the Alaska-Aleutian Range batbolith: U.S. Geol. Survey Jour. Resesrch, v. 2, no. 3, p. 343-352.

\section{KETCHIKAN QUADRANGLE}

Alaske Division of Geological and Geophysical Surveys, 1974, Annual Report 1973: Anchorage, Alaska, $59 \mathrm{p}$ :

Berg, H. C., 1973, Geology of Gravine Island, Alaska: U.S. Geol. Survey Bull. 1373, 41 p.

Berg, H. C., and others, 1974, Magnetic tape containing spectrographic and chemical analyses of rock and stream-sediment samples from the Granite Flords W1Iderness Study Area, Alaska: Natl. Tech. Inf. Service PB-232 049, magnetic tape.

Carter, clatre, ed., 1974, United states Geologlcal Survey Alaska Program, 2974: U.S. Ceol. Survey Circ. 700, 63 p. 


\section{KILLIK RIVER QUADRANGLE}

Bottge, R. G., 1974, Potential mineral resources in selected D.2 lands: U.S. Bur. Mines open-file rept. $9-74,55$ p. Also released as Natl. Tech. Inf. Service PB 227 018/AS.

\section{KISKA QUADRANGLE}

Alpha, T. R., 1974, Bering sea, orthographic drawing: U.S. Geol. Survey open-file map, I sheet.

\section{KODIAK QUADRANGLE}

Belkman, H. M., 1974, Preliminary geologic map of the southwest quadrant of Alaska: U.S. Geol. Survey Misc. Field Studies Map MF-61I, 2 sheets, scale 1:1,000,000.

Carter, Claire, ed., 1974, United States Geological Survey Alaska Program, 1974: U.S. Geol. Survey Circ. 700, 63 p.

Mackevett, E. M., Jr., and Plafker, George, 1974, The Border Ranges fault in south-central Alaska: U.S. Geol. Survey Jour. Research, v. 2 , no. 3 , p. 323-329.

U.S. Geological Survey, 1973, Geological Survey research 1973: U.S. Geol. Survey Prof. Paper 850, 366 p.

\section{KUSKOKWIM BAY QUADRANGLE}

Alpha, T. R., 1974, Bering Sea, orthographic drawing: U.S. Geol. Survey open-file map, 1 sheet.

Beikman, H. M., 1974, Preliminary geologic map of the southwest quadrant of Alaska: U.S. Geol. Survey Misc. Field Studies Map MF-611, 2 sheets, scale 1:1,000,000.

\section{KWIGUK QUADRANGLE}

Belkman, H. M., 1974, Preliminary geologic map of the southwest quadrant of Alaska: U.S. Geol. Survey Misc. Field Studies Map MF-61l, 2 sheets, scale $1: 1,000,000$. 


\section{LAKE CLARK QUADRANGLE}

Belkman, H. M., 1974, Preliminary geologic map of the southwest quadrant of Alaska: U.S. Geol. Survey Misc. Fleld Studies Map MF-6Il, 2 sheets, scale 1:1,000,000.

Bottge, R. G., 1974, Potential minerel resources in selected D.2 lands: U.S. Bur. Mines open-P1le rept. 9-74, 55 p. Also released as Natl. Tech. Inf. Service PB 227 018/AS.

Detterman, R. I., and Reed, B. L., 1973, Surficial deposits of the Illama quadrangle, Alaska: U.S. Geoz. Survey Bull. 1368-A, p. AlA64.

Lahr, J. C., Page, R. A., and Thomes, J. A., 1974, Catalog of earthquakes in south central Alaska, Apr1l-June 1972: U.S. Geol. Survey open-file report, $35 \mathrm{p}$.

Marvin, R. F., 2974, A tabulation of K-Ar, Rb-Sr, and Pb-c ages obtalned From materials within the United States (including Alaska and Rawai1) during the years 1969 through 1971: U.S. Geol. Survey open-file report, $193 \mathrm{p}$.

Reed, B. I., and Lanphere, M. A., 1974, Chemical variations across the Alaska-Aleutlan Range bathollth: U.S. Geol. Survey Jour. Research, v. 2, no. 3, p. 343-352.

\section{LIME HILLS QUARRANGLE}

Betkman, H. M., 2974, Preliminary geologic map of the southwest quadrant of Alaska: U.S. Geol. Survey Misc. Field Studies Map MF-6ll, 2 sheets, scale $1: 1,000,000$.

Bottge, R. G., 1974, Potential mineral resources in selected 0.2 lands: U.S. Bur. Mines open-file rept. 9-74, 55 p. Also releesed as Natl: Tech. Inf, Service PB $227018 / \mathrm{AS}$.

Marvin, R. F., 1974, A tabulation of K-Ar, Rb-Sr, and Pb-a ages obtained from materials w1thin the United States (Including Alaska and Hawa11) durlng the years 1969 through 1971: U.S. Geol. Survey open-f1le report, $193 \mathrm{p}$.

Reed, B. L., and lanphere, M. A., 1974, Chemfcal variations across the Alaska-Aleutian Range batholith: U.S. Geol. Survey Jour. Research, v. 2, no. 3, p. 343-352. 


\section{LIVENGGOD QUADRANGLE}

Alaska Division of Geological and Geophysical Surveys, 1974, Annual Report 2973: Anchorage, Alaska, $59 \mathrm{p}$.

Chllders, J. M., 1974, Flood surveys along TAPS route, Alaska: U.S. Geol. Survey open-file report, $16 \mathrm{p}$.

Mulligan, J.J., 1974, Mineral resources of the trans-Alasks plpeline corrtdor: U.S. Bur. Mines Inf. C1rc. 8626, 24 p.

Neuman, J. W., and Kemodle, D. R., 1974, Aquatic organisms Prom selected sites along the proposed trans-Alaske plpeline corridor, September 1970 to September 1972: U.S. Geol. Survey open-f1le report, $23 \mathrm{p}$.

U.S. Geological Survey, 1974, Aeromagnetic map of eastern half of the Ilvengood quadrangle, northeastern Alaska: U.S. Geol. Survey openPlle map, I sheet, scale 1:250,000.

U.8. Geological Survey, 1974, Aeronagaet1c map of eastern half of the Ilvengood quadrangle, northeastern Alaska: U.S. Geol. Survey openI1le map, 12 sheets, scale $1: 63,360$.

\section{MARSHALL QUADRANGLE}

Alpha, T. R., 1974, Bering Sea, orthograph1c drawlng: U.S. Geol. Survey open-file map, 1 sheet.

Belkman, H. M., 1974, Preliminary geologic map of the southwest quadrent of Alaska: U.S. Geol. Survey Mise. Field Studies Map MF-611, 2 sheets, scale $1: 1,000,000$.

\section{MCCARTHY QUADRANGLE}

Alagka Diviston of Geological and Geophysical Surveys, 1974, Annual Report 1973: Anchorage, Alaska, 59 p.

Bottge, R. G., 197.4, Potential meral resources in selected D.A lands: U.S. Bur. Mines open-file rept. 9-74, 55 p. Also released as Natl. Tech. Inf. Service PB 227 018/AS.

Carter, Claire, ed., 1974, United States Geologleal Survey Alaska Program, 1974: U.S. Geol. Survey C1re. 700, 63 p.

Mackevett, E. M, IY, 1973, Recomralssance geologic map of the McCarthy A-5 quadrangle, Alaska! U.S. Geol. Survey Misc. Fleld Studies Map MF-536, 1 sheet, scale 1:63,360.

Mackevett, E. M., Jr., and Planker, George, 1974, The Border Ranges fault in south-central Alaska: U.S. Geol. Survey Jour. Research, v. 2 , no. 3 , p. 323-329. 


\section{MCCARTHY QUADRANGLE}

Mackevett, E. M., Jr., and Smith, J. G., 1972, Geologlc map of the McCarthy B-6 quadrangle, Alaska: U.S. Geol. Survey Geol. Quad. Map GQ-1035, I sheet, scale 1:63,360.

Marvin, R. F., 1974, A tabulation of $\mathrm{K}-\mathrm{Ar}, \mathrm{Rb}-\mathrm{Sr}$, and Pb-x ages obtalned. Prom materials within the United States (1ncluding Alaska and Hawa11) during the years 1956 through 1964: U.S. Geo1. Survey open-file report, $174 \mathrm{p}$.

Marvin, R. F., 1974, A tabulation of K-Ar, Rb-Sr, and Pb-r ages obtalned from materials within the United States (Including Alaska and Hawai1) during the years 1965 through 1968: U.S. Geol. Survey open-file report, $245 \mathrm{p}$.

Marvin, R. F., 1974, A tabulation of K-Ar, Rb-Sr, and Pb-ai ages obtained from materials within the United States (Including Alaska and Hawai1) during the years 1969 through 1971: U.S. Geol. Survey open-f1le report, $193 \mathrm{p}$.

U.s. Geological survey, 1973, Geological survey research 1973: U.S. Geol. Survey Prof. Paper 850, 366 p.

\section{MCGRATH QUADRANGLE}

Alaska Division of Geological and Geophysical Surveys, 1974, Annual Report 1973: Anchorage, Alaska, 59 p.

Belkman, H. M., 1974, Preliminary geologic map of the southwest quad-. rant of Alaska: U.S. Geol. Survey Misc. Field Studies Map MF-611, 2. sheets, scale $1: 1,000,000$.

Carter, claire, ed., 1974, United States ceologlcal Survey Alaska

- Program, 1974: U.S. Geol. Survey C1rc. 700, 63 p.

\section{MEADE RIVER QUADRANCLE}

U.S. Géological survey, 1973, Geological survey research 1973!

U.S. Geol. Survey Prof. Paper 850,366 p.

\section{MFDFRA QUADRANGLE}

Belkman, H. M., 1974, Preliminary geologic map of the southwest quadrant of Alaska: U.S. Geol. Survey Misc. Fleld Stuales Map MF-611, 2 sheets, scale $1: 1,000,000$.

Carter, cla1re, ed., 1974, United states Geological survey Alaska Program, 1974: U.S. Geol. Survey Cire. 700, 63 p.

Marvin, R. F., 1974, A tabulation of K-Ar, Rb-Sr, and Pb-x ages obtained from materials within the United States (including Alaska and Bawal1) during the years 1956 through 1964: U.S. Geol. Survey open-file report, $174 p$. 


\section{MIDDLETON ISLAND QUADRANGLE}

Plafkex, George, 1974, Preliminary geologic mep of Kayak and Wingham Islands, Alaska: U.S. Geol. Survey open-file map 74-82, 1 sheet, scale 1:31,680.

U.8. Geologlcal survey, 1973, Geologlcal survey research 1973:

U.S. Geol. Survey Prof. Paper 850, 366 p.

\section{MISHESUK MOUNTAIN QUADRANGLE}

U.S. Geological Survey, 1973, Geological survey research 1973:

U.S. Geol. Survey Prof. Paper 850, 366 p.

\section{MOUNT FAIRWEATHER QUADRANGLE}

Carter, clafre, ed., 1974, United States Geological Survey Alaska Program, 1974: U.S. Geol. Survey C1rc. 700, 63 p.

\section{MOUNT HAYES QUADRANGLE}

Alaska Division of Geological and Geophysical Surveys, 1974, Annual Report 1973: Anchorage, Alaska, 59 p.

- Chllders, J. M., 1974, Flood surveys along MAPS route, Alaska: U.S. Geol. Survey open-file report, $16 \mathrm{p}$.

Marvin, R. F., 1974, A tabulation of $\mathrm{K}-\mathrm{Ar}, \mathrm{Rb}-\mathrm{Sr}$, and $\mathrm{Pb}$ re ages obtained from materials within the United States (Including Alaska and Hawai1) during the years 1965 through 1968: U.S. Geol. Survey open-file report, $245 \mathrm{p}$.

Miligan, J. J., 1974, Mineral resources of the trans-Alaska pipeline corridor: U.S. Bur. Mines Inf. C1rc. 8626, 24 p..

Nauman, J. W., and Kernodle, D. R., 1974, Aquatic organisms Irom selected sites along the proposed trans-Alaska plpeline corridor, September 1970 to september 1972: U.S. Geol. Survey open-f1le report, $23 \mathrm{p}$.

U.S. Geological Survey, 1973, Geological survey research 1973:

U.S. Geol. Survey Prop. Paper 850,366 p. 
Belloman, R. H., 1974, Preliminary geologic map of the southirest quadrant of Alaska: U.S. Geol. Survey M1sc. Fleld Studies Map MF-61l, 2 sheets, scale $1: 1,000,000$.

Bottge, R. G., 1974, potential mineral resources in selected D.2 lands: U.S. Bur. Mines open-file rept. 9-74, 55 p. Also released as Natl. Tech. Inf. Service PB 227 018/AS.

Dettermen, R. L., and Reed, B. L., i973, Surficlal deposits of the Illamna quadrangle, Aleska: U.S. Geol. Survey Bull. 1368-A, P. AlA64.

Marv1n, R. F., 1974, A tabulation of K-Ar, Rb-Sr, and Pb-a ages obtained from materials within the United States (including Alaska and Hawa11) durlng the years 1969 through 1971: U.S. Geol. Survey open-f110 report, $193 \mathrm{p}$.

\section{MOUNT MCKINLEY QUADRANGLE}

Alaska Divislon of Geological and Goophysical Surveys, 1974, Annual Report 1973: Anchorage, Alaska, 59 p.

Belkman, H. M., 1974, Preliminary geologie map of the southwest quadrant of Alaska: U.S. Geol. Survey Mac. Fleld Studies Map MF-6II, 2 sheets, scale 1:1,000,000.

Bottge, R. G., 1974, Potential mineral resources in selected D.2 lands: U.S. Bur. Mines open-file rept. 9-74, 55 p. Also released as Natl. Tech. Inf. Service PB 227 018/AS.

\section{MOUNP MICHELSON QUADRANGLE}

Carter, claire, ed., 1974, United states Geological survey Alaska Program, 1974: U.S. Geol. Survey Circ. 700, 63 p.

Detterman, R. I., 1974, Fence diagram showing lithologic facies of the Sadlerochit Formation (Permian and lower Trlassic), northeastern Alaska: U.S. Geol. Survey Misc. Fleld Studies Map MF-584, 1 sheet.

Marvln, R. F., 1974, A tabulation of K-Ar, Rb-SY, and Pb-ce ages obtalned from materials within the United States (Including Alaska and Hawa11) during the years 1965 through 1968: U.S. Geol. Survey open-flle report, $245 \mathrm{p}$.

U.8. Ceological survey, 1973, ceological survey résearch 1973: U.S. Geol. Survey Prof. Paper 850, 366 p.

Worl, R. G., Van Alstine, R. E., and Heyl, A. V., 1974, Fluortte in the United States (exclusive of Hawa11): U.S. Geol. Survey Mineral Inv. Resources Map MR-60, 13 p., I sheet. 


\section{NABESNA QUADRANGLE}

Alaska Division of Geological and Geophysical Surveys, 1974, Annuel Report 1973: Anchorage, Alaska, 59 p.

Bottge, R. G., 1974, Potentlal mineral resources in selected D.2 lands: U.S. Bur. Mines open-file rept. 9-74, 55 p. A3so released as Natl. Tech. Inf. Service PB $227018 / \mathrm{AS}$.

Carter, Claire, ed., 1974, Urited States Geolo"ical Survey Alaska Program, 1974: U.S. Geol. Survey C1rc. 700, 63 p.

Mackevett, E. M., Ir., and Plafker, George, 1974, The Border Ranges fault in south-central Alaska: U.S. Geol. Survey Jour, Research, v. 2, no. 3, p. 323-329.

Marvin, R. F., 1974, A tabulation of K-Ar, Rb-SY, and Pb-cages obtained from materials within the United States (including Alaska and Hawai1) during the years 1969 through 1971: U.S. Geol. Survey open-P1le report, 193 p.

R1chter, D. H., 1973, Reconnaissance geologic map of the Nabesna A-4 quadrangle, Alaska: U.S. Geol. Survey Misc. Geol. Inv. Mnp I-789, 1 sheet, scale 1:63,360.

Richter, D. R., Matson, N. A., Jr., and Schmoll, R. R., 1973, Reconnalssance geologic map of the Nabesna A-l quadrangle, Alaska: U.S. Geol. Survey Misc. Geol. Inv. Map I-807, I sheet, scale 1:63,360.

Richter, D. H., and Schmoll, B. R., 1973, Geologtc map of the Nabesne C-5 quadrangle, Alaska: U.S. Geol. Survey Geol. Quad. Map GQ-1062, 1 sheet, scale 1:63,360.

U.S. Geological survey, 1973, Geological survey research 1973! U.S. Geol.' Survey Prof. Paper 850, 366 p.

\section{NAKNEX QUADRANGLE}

Be1kman, R. M., 1974, Prellminary geologle map of the southwest quadrant of Alaska: U.S. Geol. Survey Misc. Fleld Studses Map MF-6Ll, 2 sheets, scale 1:1,000,000.

Detterman, R. L., and Reed, B. L., 1973, Surficlal deposits of the Illama quadrangle, Alaska: U.S. Geol. Survey Bull. 1368-A, p. AlA64.

Marvin, R. F., 1974, A tabulation of $\mathrm{X}-\mathrm{Ar}, \mathrm{Rb}-\mathrm{Sr}$, and Pb-o ages obtalned Prom materials within the United States (Inclualng Alaska and Hawai1) during the years 1969 through 1971: U.S. Geol. Survey open-file report, $193 \mathrm{p}$. 


\section{NOATAK QUADRANGLE}

Grantz, Arthur, Mellendrie, A. G., Nilsen, T. F., and Yorath, C. J., 1974, Selsmic reflection proftles on the continental shelf and slope between Bering Strait and Barrow, Alaska, and Mackenzie Bey, Canada: U.S. Geol. Survey open-file rept., 51 sheets.

Grantz, Arthur, McFendrie, A. G., Nilsen, T. H., Yorath, C. J., and Phillips, J. D., 1974, Digital magnetic tapes of' single channel seismic reflection profiles on the continental shelf and slope between Bering Strait und Barrow, Alaska, and Mackenzie Bay, Canada: Natl. Tech. Inf. Service PB-232 344, 12 p.

Hanna, W. F., Ruppel, D. B., Mckenarie, A. G., and Sikora, R. F., 1974, Residual magnetic anomaly and free-air gravity anomaly profiles, 1973, on continental shelf and slope between Berlng strait and Barrow, Alaska, and Mackenzie Bey, Canada: U.S. Geol. Survey openflle report $74-6,6$ sheets.

\section{NOME QUADRANGLE}

Alaska Division of Geological and Geophysical Surveys, 1974, Annual Report 1973: Anchorage, Alaska, 59 p.

Belkman, H. M., 1974, Preliminary geologic map of the southwest quadrant of Alaska: U.S. Geol. Survey Misc. Fleld Studies Map MF-611, 2 sheets, scale $1: 1,000,000$.

U.S. Geological survey, 1973, Geological survey research 1973! U.S. Geol. Survey Prof. Paper 850, 366 p.

Worl, R. G., Van Alstine, R. E., and Heyl, A. V., 1974, Fluorite in the United States (exclusive of Hawail): U.S. Geol. Survey Mineral Inv. Resources Map MR-60, 13 p., I sheet.

\section{NORTON BAY QUADRANGLE}

Beikmax, H. M., 19.74, Brellatnary gealogic map of the southwest quadrant of Alaska: U.S. Geol. Survey Misc. Fleld Studies Map MF-611, 2 sheets, scale 1:1,000,000.

\section{NULATO QUADRANGLE}

Belkman, H. M., 1974, Preliminary geologic map of the southwest quadrant of Alaska: U.S. Geol. Survey Misc. Field Studies Map MF-61l, 2 sheets, scale 1:1,000,000. 


\section{NUNIVAK ISLAND QUADRANGLE}

Alpha, T. R., 1974, Bering Sea, orthographic drawing: U.S. Geol. Survey open-file map, 1 sheet.

Belkman, H. M., 1974, Preliminary geologic map of the southwest quadrant of Alaska: U.S. Geol. Survey Misc. Field Studies Map MF-6II, 2 sheets, scale $1,2,000,000$.

Carter, claire, ed., 1974, United states Geologlcal Survey Alaska Program, 1974: U.S. Geol. Survey C1rc. 700, 63 p.

Marvin, R. F., 1974, A tabulation of K-Ar, Rb-Sr, and Pb ages obtalned from materials within the United States (Including Alaska and Bawa11) durling the years 1965 through 1968: U.S. Geol. Survey open-f1le report, $245 \mathrm{p}$.

\section{NUSHAGAK BAY QUADRANGLE}

Beikman, H. M., 1974, Prelininary geologic map of the southwest quadrant of Alaska: U.S. Geol. Survey Misc. Field Studles Map MF-6II, 2 sheets, scale 1:1,000,000.

\section{OPHTR QUADRANGLE}

Belkman, H. M., 1974, Preliminary geologic map of the southwest quadrant of Alaska: U.S. Geol. Survey Misc. Field Studies Map MF-6II, 2 sheets, scale $1: 1,000,000$.

\section{PETETSBURG QUADRANGLE}

Alasks Division of Geological and Geophysical Surveys, 1974, Annual Report 1973: Anchorage, Alaska, 59 p.

Lerke, R. W., 1974, Reconnaissance engineering geology of the Wrangell area, Alaska, with emphasts on evaluation of earthquakes and other geologic hazards: U.S. Geol. Survey open-file report, 103 p.

Marv1n, R. F., 1974, A tabulation of K-Ar, Rb-Sr, and Pb-ce ages obtained from materials within the United States (Including Alaska and Hawa11) during the years 1965 through 1968: U.S. Geol. Survey open-f1le report, $245 \mathrm{p}$.

Worl, R. G., Van Alstine, R. E., and Heyl, A. V., 1974, Fluorlte in the United States (exclusive of Hawa11): U.S. Geol. Survey Mineral Inv. Resources Map MR-60, 13 p., I sheet. 


\section{PHILIP SMITH MOUNTAINS QUADRANGLE}

Chtlders, J. M., 1974, Flood surveys along TAFS route, Alaska! U.S. Geol. Survey open-file report, $16 \mathrm{p}$.

Millgan, J.J., 1974, Mineral resources of the trans-Alaska plpeline corridor: U.S. Bur. Mines Inf. C1rc. 8626,24 p.

Haumen, J. W., and Kernodle, D. R., 1974, Aquatic organt stus from selected sites along the proposed trans-Alaska pipeline corridor, September 1970 to September 1972: U.S. Geol. Survey open-11le report, $23 \mathrm{p}$.

\section{POINT HOPE QIJADRANGLE}

Carter, cla1re, ed., 1974, United States Geological Survey Alaska Program, 1974: U.S. Geol. Survey Clrc. 700, 63 p.

Granti, Arthur, McHendrie, A. G., Nilsen, N. H., and Yorath, C. J., 1974, Selsaic reflection profiles on the contluental shelf and slope between Bering Strait and Barrow, Alaska, and Mackenzie Bay, Canada: U.S. Geol. Survey open-f1le rept., 51 sheets.

Grantz, Arthur, MeHendrie, A. G., N1lsen, T. H., Yorath, C. J., and Phillips, J. D., 1974, Digital magnetic tapes of single channel selsuic reflection propiles on the continental sbeif and slope between Bering Strait and Barrow, Alaska, and MacKenzle Bay, Canada: Natl. Tech. Inf. Service PB-232 344, 12 p.

Banne; W. F., Ruppel, D. B., McHerdrte, A. G., and S1kora, R. F., 1974, Residual magnetic anomaly and free-air gravity anomaly profiles, 1973, on continental shelf and slope between Bering stralt and Barrow, Alaska, and MacKenzie Bay, Canada: U.5. Geol. Survey openfile report $74-6,6$ sheets.

\section{POINT LAY QUADRANGLE}

Grantz, Arthur, Mckendrle, A. G., Nilsen, T. H., and Yorath, C. J., 1974, Selsmic reflection profiles on the continental shelf and slope between Bering Strait and Barrow, Alaska, and Mackenzie Bay, Canada: U.S. Geol. Survey open-P1le rept., 51 sheets.

Grantz, Arthur, McHendrle, A. G., Nilsen, T. R., Yorath, C. J., and Phillips, J. D., 1974, Digital maguetic tapes of single channel selsmic reflection profiles on the continental shelf and slope between Bering Strait and Barrow, Alaska, and Mackenzle Bay, Canada: Natl. Tech. Inf. Service PB-232 344, 12 p.

Hanne, W. F., Ruppe1, D. B., Mchendrie, A. G., and Gikora, R. F., 1974, Residual magnetic anomaly and free-air gravity anomaly profiles, 1973, on continental shelf and slope between Bering stralt and Berrow, Alaska, and Mackenzle Bey, Canada: U.S. Geol. Survey openI1le report $74-6,6$ sheets. 
Marvin, R. F., 1974, A tabulation of K-Ar, Rb-Sr, and Pb-re ages obtalned from materials within the United States (Including Alaska and Hawa11) during the years 1965 through 2968: U.S. Geol. Survey open-f1le report, $245 \mathrm{p}$.

Teble, L. A., 1974, Reconnelssance engineering geology of Sitka and vicialty, Alaska, with emphasis on evaluation of earthquake and other geologic hazards: U.S. Geol. Survey open-file report 74-53, $104 \mathrm{p}$.

\section{PORT MOLLE' QUADRANGIE}

Alaska Division of Geological and Geophysical Surveys, 1974, Annual Report 1973: Anchorage, Alaska, 59 p.

Marvin, R. F., 1974, A tabulation of $\mathrm{K}-\mathrm{Ar}, \mathrm{Rb}-\mathrm{Sr}$, and $\mathrm{Pb}-\boldsymbol{c}$ ages obtalned from materials within the United States (Including Alaske and Hawa11) during the years 1965 through 1968: U.S. Geol. Survey open-11le report, 245 p.

\section{PRIBILOF ISLANDS QUADRANGLE}

Alpha, T. R., 1974, Bering sea, orthographic drawling: U.s. Geol. Survey open-file map, 1 sheet.

Marvin, R. F., 1974, A tabulation of K-Ar, Rb-Sr, and Pb-re ages obtained from materials within the United States (Including Alaska and Hawa11) during the years 1965 through 1968: U.S. Geol. Survey open-111e report, $245 \mathrm{p}$.

\section{PRINCE RUPERT QUADRANGLE}

Marvin, R. F., 1974, A tabulation of K-Ar, Rb-5r, and Pb-xages obtalned from materials.within the United States (1ncluding Alaska and Hawai1) during the years 1956 through 1964: U.S. Geol. Survey open-f1le report, $174 \mathrm{p}$.

Marvin, R. F., 1974, A tabulation of K-Ar, Rb-Sr, and Pb-c ages obtained from materials within the United States (Including Aladka and Hawa11). durlng the years 1965 through 1968: U.S. Geol. Survey open-file report, $245 \mathrm{p}$. 
Alpha, r. R., 1974, Bering Sea, orthographle drawing: U.S. Geol. Survey open-file map, 1 sheet.

Carter, Clalre, ed., 1974, United States Geological Survey Alaska Program, 1974: U.S. Geol. Survey C1rc. 700, 63 p.

Marvin, R. F., 1974, A tabulation of $\mathrm{K}-\mathrm{Ar}, \mathrm{Rb}-\mathrm{Sr}$, and $\mathrm{Pb}-\mathrm{a}$ ages obtalned from terials within the United States (Including Aiaska and Hawa11) durling the years 1969 through 1971: U.S. Geol. Survey open-P1le report, $193 \mathrm{p}$.

V.8. Geological survey, 1973, Geologtcal survey research 1973! U.S. Geol. Survey Prof. Paper 850, 366 p.

\section{RUBY QUADRANGLE}

Alaska Diviston of Geologtcal and Geophysical Surveys, 1974, Annual Report. 1973: Anchorage, Alaska, 59 p.

Belkman, R. M., 1974, Preliminary geologic map of the southwest quadrant of Alaska: U.S. Geol. Survey Misc. Fleld Studies Map MF-611, 2 sheets, scale 1:1,000,000.

Marvin, R. F., 1974, A tabulation of $\mathrm{K}-\mathrm{Ar}, \mathrm{Rb}-\mathrm{Sr}$, and $\mathrm{Pb}-\mathrm{x}$ ages obtalned from materials within the Untted States (Including Alaske and Hawa11) during the years 2956 through 2964: U.S. Geol. Survey open-f1le report, $174 \mathrm{p}$.

\section{RUSSIAN MISSION QUADRANGLE}

Belkman, H. M., 1974, Preliminary geologic map of the southwest quadrant of Alaska: U.S. Geol. Survey Misc. Fleld Studles Map MF-611, 2 sheets, scale 1:1,000,000. 


\section{SAGAVANIRKTOK QUADRANGLE}

Chlldera, I. M., 1974, Flood surveys along TAPS route; Alaska: U.s. Geol. Survey open-file report, $16 \mathrm{p}$.

Detterman, R. I., 1974, Fence diggram showing lithologic facles of the Sedlerochit Formation (Permian and lower Triasa1c), northeastern Alaska: U.S. Geol. Survey Misc. Fleld Studies Map MF-584, 1 sheet.

Mullgan, J.J., 1974, Minerel resources of the trans-Alasica plpeline corrtdor: U.S. Bur. Mines Inf. Clre. 8626, 24 p.

Mauman, J.W., and Kernodle, D. R., 1974, Aquatlc organd sms frón selected sites along the proposed trans-Alaska pipeline corridor, September 1970 to September 1972: U.S. Geol. Survey open-11le report, 23 p.

U.S. Geological Survey, 1973, Geological Survey research 1973! U.S. Geol. Survey Prof. Paper 850, $360^{\circ}$ p.

\section{SAIN LAWRENCE QUADRANGLE}

Alpha, T. R., 1974, Bering Sea, orthographic drawing: U.S. Geol. Survey open-file map, 1 sheet.

Befkman, 8. M., 1974, Preliminary geologle map of the southwest quadrant of Alaska: U.S. Geol. Survey Misc. Fleld Studies Map MF-6ll, 2 sheets, scale $1: 1,000,000$.

Csejtey, Béla, Jr., and Patton, W. W., Jr., 1974, Petrology of the nepheline syenlte of St. Lawrence Island, Alaska: U.S. Ceol. Survey Jour. Reseorch, v. 2, no. 1, p. 41-47.

Marvin, R. F., 1974, A tabulation of $\mathrm{K}-\mathrm{Ar}, \mathrm{Ab}-\mathrm{Sr}$, and $\mathrm{Pb}-\mathrm{a}$ ages obtained from materials within the United States (including Alaska and Hawa11) during the years 1969 through 1971: U.S. Geol. Survey open-f1le report, $193 \mathrm{p}$.

U.s. Geological survey, 1973, Geological survey research 1973: U.S. Geol. Survey Prof. Paper 850, 366 p.

\section{SAINT MATTHEW QUADRANGLE}

Alphe, T. R., 1974, Bering Sea, orthographte drawing: U.S. Geol. Survey open-file map, 1 sheet.

Belkman, H. M., 1974, Preliminary geologlc map of the southwest quadrant of Alaska: U.S. Geol. Survey MiBc. Field Studies Map MF-611, 2 sheets, scale 1:1,000,000.

Carter, clalre, ed., 1974, United States Geological Survey Alaska Program, 1974: U.S. Geol. Survey Cire. 700, 63 p. 
Betkman, H. M., 1974, Preliminary geologic map of the southwest quadrant of Alaska: U.S. Geol. Survey Misc. Field Studies Map MF-611, . 2 sheets, scale 1:1,000,000.

\section{SAMALGA ISLAND QUADRANGLE}

Alpha, T. R., 1974; Bering Sea, orthographic drawing: U.S. Geol. Survey, open-file map, 1 sheet.

\section{SEGUAM QUADRANGLE}

Alpha, T. R., 2974, Bering Sea, or hographic drating: U.S. Geol. Survey open-file map, 1 sheet.

\section{SELAWIK QUADRANGLE}

Bottge, R. G., 1974, Potential mineral resources in selected D.2 lands: U.S. Bur. Mines open-f1le rept. 9-74, 55 p. Also released es Nat1. Tech. Inf. Service PB 227 O18/AS.

Marvin, R. F., 2974, A tabulation of $\mathrm{K}-\mathrm{Ar}, \mathrm{Bb}-\mathrm{Sr}$, and $\mathrm{Pb}-\infty$ ages obtained from materials within the Uafted States (Including Alaska and Hawa11) durlag the years 1965 through 1968: U.S. Geol. Survey open-file report, $245 \mathrm{p}$.

\section{SELDOVIA QUADRANGLE}

Belkman, H. M., 1974, Preliminary geologic map of the southwest quadrant of Alaska: U.S. Geol. Survey Misc. Field Studies Map MF-6ll, 2 sheets, scale $1: 1,000,000$.

Blasko, D. P., 1974, Natural gas flelde -- Cook Inlet besin, Alasks: U.S. Bur. Mines open-f1le report $35-74,24$ p. Also released as Nati. Tech. Inf. Service PB 235 767-AS.

Carter, Clalre, ed., 1974, United States Geological Survey Alaska - Program, 1974: U.S. Geol. Survey C1rc. 700,63 p.

Lahr, J. C., Page, R. A., and Thomas, J. A., 1974, Catalog of earthquakes in south central Alaska, April-June 1972: U.S. Geol. Survey open-file report, $35 \mathrm{p}$.

Mactevett, E. M., Jr., and Plafker, George, 1974, The Border Ranges pault in soutb-central Alaska: U.S. Geol. Survey Jour. Research, จ. 2, no. 3, p. 323-329. 
Carter, clatre, ed., 1974, Undted States Geologicail Survey Alaska Program, 1974: U.S. Geol. Survey Circ. 700, 63 p.

Lahr, J. C., Page, R. A., and Thomas, J. A., 1974, Catalog of earthquakes in south central Alaska, Apr11-June 1972: U.S. Geol. Survej open-file report, $35 \mathrm{p}$.

Mackevett, E. K., Ir., and Plafker, George, 1974, The Border Ranges fault in south-central Alaska: U.S. Geol. Survey Jour. Regfarch, v. 2, no. 3, p. 323-329.

Marvin, R. F., 1974, A tabulation of K-Ar, Rb-Sr, and Pb-c ages obtained from materials within the United States (Including Alaska and Hawa11) during the years 1965 through 1968: U.S. Geol. Survey open-file report, $245 \mathrm{p}$.

U.8. Geological survey, 1973, Geological survey research 1973! U.S. Geol. Survey Prof. Paper 850, 366 p.

Zenone, Chester, 1974, Ceology and water resources of the GirdwoodAlyeska area, Alaska: U.S. Geol. Survey open-Ille report, 24 p.

\section{SHISHMAREF QUADRANGLE}

Grantz, Arthur, Melfendrie, A. G., Nilsen, T. K., and Yorath, C. J., 1974, Selsmle reflection profiles on the continental shelf and slope between Bering Strait and Barrow, Alaska, and Mackenzie Bay, Canada: U.S. Geol. Survey open-file rept., 51 sheets.

Grantz, Arthur, MeHenarie, A. G., Nilsen, T. H., Yorath, C. J., and Ph1llips, J. D., 1974, Digital magnetic tapes of single channel selsmic reflection profiles on the continental shelf and slope between Bering Strait and Barrow, Alaska, and MacKenzle Bay, Canada: Natl. Tech. Inf. Service PB-232 344, 12 p.

Hanna, W. F., Ruppel, D. B., Meliendrie, A. G., and sikora, R. F., 1974, Residual magnetic anomaly and free-air gravity anomaly profiles, 1973, on continental shelf and slope between Bering strait and Barrow, Alaska, and Mackenzie Bay, Canada: U.S. Geol. Survey openfile report $74-6,6$ sheets.

\section{SHUNGNAK QUADRANGLE}

Bottge, R. G., 1974, potential mineral resources in selected D.2 lands: U.S. Bur. Mines open-file rept. 9-74, 55 p. Also released as Natl. Tech. Inf. Service PB 227 018/AS.

Marvin, R. F., 1974, A tabulation of K-Ar, Rb-5r, and Pb- ages obtained from materials within the United States (Including Alaska and Hawai1) during the years 1965 through 1968: U.S. Geol. Survey open-file report, $245 \mathrm{p}$. 
Aleska Division of Geological and Geophysicel Surveys, 1974, Annual Report 1973: Anchorage, Alaska, 59 p.

Cartar, Cla1re, ed., 1974, Unlted States Geological Survey Alaska Program, 1974: U.S. Geol. Survey Circ. 700, 63 p.

Marvin, R. F., 1974, A tabulation of $\mathrm{K}-\mathrm{Ar}, \mathrm{Rb}-\mathrm{Sr}$, and Pb-ar ages obtained from materials within the United States (Including Alaska and Hawa11) durlng the years 1965 through 1968: U.S. Geol. Survey operpille, report, $245 \mathrm{p}$.

Yehle, L. A., 1974, Reconnalssance engineering geology of s1 tka and vicinity, Alaska, with emphasis on evaluation of earthquake and otber geologic hazards: U.S. Geol. Survey open-file report 74-53, 104 p.

\section{SKAGWAY QUADRANGLE}

Alaska Division of Geological and Geophysical surveys, 1974, Annual Report 1973: Anchorage, Alaska, 59 p.

Carter, Cla1re, ed., 1974, United States Geological survey Alaske Program, 1974: U.S. Geol. Survey C1rc. $700,63 \mathrm{p}$.

Mackevett; E. Mo, Jr., Robertson, E. C., and winkler, G. R., 1974, Geology of the Skagway B-3 and B-4 quadrangles, southeastern Alaska: U.S. Geol. Survey Prof. Paper 832, 33 p.

Marvin, R. F., 1974, A tabulation of $\mathrm{K}-\mathrm{Ar}, \mathrm{Rb}-\mathrm{Sr}$, and $\mathrm{Pb}-x$ ages obtained Prom materials within the United States (Including Alaska and Hawa11) during the years 1956 through 1964: U.S. Geol. Survey open-file report, $174 \mathrm{p}$.

\section{SLEETMUTE QUADRANGLE}

Beikman, R. M., 1974, Preliminary geologic map of the southwest quadrant of Alaska: U.S. Geol. Survey Misc. Field Studies Map MF-611, 2 sheets, scale $1: 1,000,000$.

\section{SOLOMON QUADRANGLE}

Belkman, H. M., 1974, Prellminary geologic map of the southwest quadrant of Alaska: U.S. Geol. Survey Misc. Field Studies Map MF-611, 2 sheets, scale $1: 1,000,000$.

Carter, Cla1re, ed., 1974, United States Geological Survey Alaska Program, 1974: U.S. Geol. Survey C1re. 700, 63 p. 
Carter, cla1re, ed., 1974, United States Geological Survey Alaska Program, 1974: U.S. Geol. Survey C1rc. 700, 63 p.

\section{SURVEY PASS QUADRANGLE}

Alaska Division of Geological and Geophysical Surveys, 1974, Annual Report 1973: Anchorage, Alaska, 59 p.

Bottge, R. G., 1974, Potentlal mineral resources in selected 0.2 lands: U.S. Bur. Mines open-P1le rept. 9-74, 55 p. Also released as Nat1. Tech. Irr. Service PB 227 018/AS.

\section{TABEE MOUNTAIN QUADRANGLE}

Detterman, R. L., 1974, Fence diagram showing lithologle facies of the Sadlerochit Formation (Permian and lower Triassic), northeastern Alaska: U.S. Ceol. Survey Mise. Fleld Studies Map MF-584, 1 sbeet.

\section{TAKO RTVER QUADRANGLE}

Carter, cla1re, ed., 1974, United States Geological Survey Alaske Program, 1974: U.S. Geol. Survey C1re. 700, 63 p.

Marvin, R. F., 1974, A tabulation of $\mathrm{K} \sim \mathrm{Ar}, \mathrm{Rb}-\mathrm{Sr}$, and $\mathrm{Pb}-x$ ages obtained from materials within the United States (1ncluding Alaska and

$\therefore$ Hawa11) during the years 1956 through 1964: U.S. Geol. Survey open-p1le report, $274 \mathrm{p}$.

Marvin, R. F., 1974, A tabulation of K-Ar, Rb-Sr, and Pb-r ages obtalned from materlals within the United States (Including Alaska and Hawai1) durlng the years 1965 through 1968: U.S. Geol. Survey open-f1le report, $245 \mathrm{p}$.

Marvin, R. F., 1974, A tebulation of $\mathrm{K}-\mathrm{Ar}, \mathrm{Rb}-\mathrm{Sr}$, and $\mathrm{Pb}-\mathrm{a}$ ages obtained rrom materials witbin the United States (including Alaska and Hawail) during the years 1969 through 1971: U.S. Geol. Survey open-r1le report, $193 \mathrm{p}$. 
Alaske Division of Geological and Geophysical Surveys, 1974, Annual Report 1973: Anchorage, Alaska, 59 p.

Betkman, H. M., 1974, Preliminary geologlc map of the southwest quadrant of Alaska: U.S. Geol. Survey Misc. Fleld Studies Map MF-61l, 2 sheets, scale $1: 1,000,000$.

Bottge, R. G., 1974, Potential mineral resources in selected $D .2$ lends: U.S. Bur. Mines open-11le rept. 9-74, 55 p. Also released as Natl. Tech. Ins. Service PB 227 018/AS.

Lahr, J. C., Page, R. A., and Thomas, J. A., 1974, Catalog of earthquakes in south central Aleska, Apr11-June 1972: U.S. Geol. Survey open-flle report, $35 \mathrm{p}$.

\section{TALKEETNA MOUNTAINS QUADRANGLE}

Aleska Division of Geological and Geophysical Surveys, 1974, Armual. Report 1973: Anchorage, Alaska, 59 p.

Carter, Cla1re, ed., 1974, United States Geological Survey Alaska program, 1974! U.S. Geol. Survey C1re. 700, 63 p.

Csejtey, Béla, Jr., 1974, Reconnalssance geologic investlgations in the Talkeetna Mountalns, Alaska: U.S, Geol. Survey open-file report $74-147,48$ p.

Hawkins, D. B., 1973, Sedimentary zeolite deposits of the upper Matanuska Valley, Alaska: Alaska Div. Geol. Geophys. Surveys Spec. Rept. 6, 17 p.

Kacbadoortan, Reuben, 1974, Geology of the Devil Canyon dam site, Alaska: U.S. Geol. Survey open-file report $74-40,17 \mathrm{p}$.

Labr, J. C., Page, R. A., and Thomes, J.A., 1974, Catalog of eartbquakes in south central Alaska, April-June 1972: U.S. Geol. Survey open-file report, $35 \mathrm{p}$.

Mariin, R. F., 1974, A tabulation of K-Ar, Rb-Sr, and Pb-x ages obtained from materials within the United States (including Alaska and Kawa11) during the years 1956 through 1964: U.S. Geol. Survey open-file report, $174 \mathrm{p}$.

Marvin, R. F., 1974, A tabulation of K-Ar, Rb-Sr, and Pb- ages obtained from materials within the United States (including Alaska and Hawa11) during the years 1965 through 1968: U.S. Geol. Survey open-file report, $245 \mathrm{p}$.

U.S. Geological survey, 1973, Geological survey résearch 1973! U.S. Geol. Survey Prof. Paper 850, 366 p. 
Alaska Dtvision of Geological and Geophysical Surveys, 1974, Arnual Report 1973: Anchorage, Alaska, 59 p.

Marvin, R. F., 1974, A tabulation of $K-A r, R b-S r$, and Pb-r ages obtained Prom materials within the United States (including Alaska and Hawai1) during the years 1956 through 1964: U.S. Geol. Survey open-file report, $174 \mathrm{p}$.

\section{TANANA QUADRANGLE}

Alakk Dfvision of Geological and Geophysical Surveys, 1974, Annual Report 1973: Anchorage, Alaska, 59 p.

Carter, cla1re, ed., 1974, United States Geological Survey Alaska Progrem, 1974: U.S. Geol. Survey C1rc. 700, 63 p.

Mulligan, J. J., 1974, Mineral resources of the trans-Alaska plpeline corridor: U.S. Bur. Mines Inf. C1re. 8626, 24 p.

U.8. Geological Survey, 1973, Geological survey research 1973! U.S. Geol. Survey Prof. Paper 850, 366 p.

TAYLOR MOUNTATNS QUADRANGLE

Belkinan, R. M., 1974, Preliminary geologlc map of the soutbwest quadrant of Alaska: U.S. Geol. Survey Misc. Field Studies Map MF-61I, 2 sheets, scale 1:1,000,000.

\section{TELLER QUADRANGLE}

Johnson, G. R., and Sainsbury, C. L., 1974, Aeromagnetic and generalized geologic map of the west-central part of the Seward Peninsula, Alaska: U.S. Geol. Survey Geophys. Inv. Map GP-881, I sheet, scale 1:125,000.

Marvin, R. F., 1974, A tabulation of K-Ar, Rb-Sr, and Pb-x ages obtalned from materials within the United States (including Alaska and Hawai1) during the ynars 1956 through 1964: U.S. Geol. Survey open-file report, $274 \mathrm{p}$.

Marvin, R. F., 1974, A tabulation of K-Ar, Rb-Sr, and Pb-a ages obtained from materials within the united States (including Alaska and Hawail) during the years 1969 through 1971: U.S. Ceol. Survey open-P1le report, $193 \mathrm{p}$.

Wor1, R. G., Van Alstine, R. E., and Heyl, A. V., 1974, Fluorlte in the United States (exclusive of Hawa11): U.S. Geol. Survey Mneral Inv. Resources Map MR-60, 13 p., 1 sheet: 


\section{TYONEK QUADRANGLE}

Belkmen, R. M., 1974, Preliminary geologlc may of the southwest quadrant of Alaska: U.S. Geol. Survey Misc. Fleld Studies Map MF-6II, 2 sheets, scale $1: 1,000,000$.

Blasko, D. P., 1974, Natural gas 11elds -- Cook Inlet besin, Alaska! J.S. Bur. Munes open-11le report $35-74,24 \mathrm{p}$. Also released as Natl. Tech. Inf. Service PB 235 767-AS.

carter, cla1re, ed., 1974, Untted States ceological Survey Alaska Program, 1974: U.S. Geol. Survey Circ. 700, 63 p.

Dearborn, L. L., and Freethey, G. W., 1974, Water-teble contour wap, Anchorage area, Alaska: U.S. Geol. Survey open-flle map, 1 sheet, scale $1: 24,000$.

Detterman, R. L., Plafker, George, Huason, Trav1s, Tysdal, R. G., and Pavont, Nazar10, 1974, Surface geology and Rolocene breaks along the Susitna segment of the Castle Mountain fault, Alaska: U.S. Geol. Survey Milac. Field Studies Map MF-618, I sheet, scale 1:24,000.

Freethey, G. W., Reeder, J. H., and Barnwell, W. W.; 1974, Map showlng deptb to water, Anchorage area, Alaska: U.S. Geol. Survey openfile map, 1 sheet, scale 1:24,000.

Lahr, J. C., Page, R. A., and Thomas, J. A., 1974, Catalog of earthquakes in south central Alaska, Aprll-June 1972: U.S. Geol. Survey open-file report, $35 \mathrm{p}$.

Marvin, R. F., 1974, A tabulation of K-Ar, Rb-Sr, and Pb-cages obtelned from materials within the United States (including Alaska and Hawa11) during the years 1969 through 1971: U.S. Geol. Survey open-file report, $193 \mathrm{p}$.

Reed, B. L., and Lanphere, M. A., 1974, Chemlcal varlations across the Alaska-Aleutian Range batholith: U.S. Geol. Survey Jour. Research, v. 2, no. 3, p. 343-352.

Schmoll, G. R., and Dobrovolny, Emest, 1974, Construction metertalo map of Anchorage and vicinity, Alaska: U.S. Geol. Survey Misc. Geol. Inv. Map I-787-C, I sheet, scale 1:24,000

Scbmoll, H. R., and Dobrovolny, Errest, 1974, Foundation and excavation conditions map of Anchorage and vicinity, Aleska: U.S. Geol. Survey Misc. Geol. Inv. Map I-787-D, I sheet, scale 1:24,000.

\section{UGASHIK QUADRANGLE}

Belkman, H. M., 1974, Preliminary geologic map of the southwest guadrant of Alaska: U.S. Geol. Survey Misc. Field Studies Map MF-611, 2 sheets, scale 1:1,000,000.

Marvin, R. F., 1974, A tabuiation of K-Ar, Rb-Sr, and $\mathrm{Pb}-\infty$ ages obtalned from materials within the United States (Including Alaska and Hawai1) durlng the years 1969 through 1971: U.S. Geol. Survey open-file report, $193 \mathrm{p}$. 
Alphe, T. R., 2974, Bering Sea, orthographic drawing: U.S. Geol. Survey open-file map, 1 sheet.

\section{UNALAKLEET QUADRANGLE}

Befloman, H. M., 1974, Prellminary geologic map of the southwest quadrant of Alaska: U.S. Geol. Survey Misc. Fleld Studles Map MF-611, 2 sheets, scale $1: 1,000,000$.

\section{UNALASKA QUADRANGLE}

Alpha, T. R., 1974, Bering Sea, orthographic drawing: U.S. Geol. Survey open-file map, 1 sheet.

UNIMAK QUADRANGLE

Alpha, T. R., 1974, Bering See, orthographic drawing! U.S. Geol. Survey open-file map, I sheet.

\section{VAIDEZ QUADRANGEE}

Bottge, R. G., 1974, Potential mineral resources in selected D.2 lands: U.S. Bur. Mines open-f1le rept. 9-74, 55 p. Also released as Natl. Tech. Inf. Service PB 227 018/AS.

carter, Claire, ed., 1974, United States Geological Survey Alaska Program, 1974: U.S. Geol. Survey Circ. 700, 63 p.

Chtlders, J. M., 1974, Flood surveys along TAPS route, Alaska: U.S. Geol. Survey open-file report, 16 p.

Lehr, J. C., Page, R. A., and Thomas, J. A., 1974, Catalog of earthquakes In south central Alaska, April-June 1972: U.S. Geol. Survey open-file report, $35 \mathrm{p}$.

Mackevett, E. M., Jr., and Plafker, George, 1974, The Border Ranges fault in south-central Alaska: U.S. Geol. Survey Jour. Research, v. 2, no. 3, p. 323-329.

Marvin, R. F., 1974, A tabulation of $\mathrm{K}$-Ar, $\mathrm{Rb}-\mathrm{Sr}$, and Pbore ages obtalned Prom materials wtthin the United States (Including Alaska and Hawa11) during the years 1965 through 1968: U.S. Geol. Survey open-file report, $245 \mathrm{p}$.

Mulligan, J. J., 1974, Mineral resources of the trans-Alaska pipeline corrtdor: U.S. Bur. Mines Inf. C1rc. 8626,24 p. 


\section{VALDEZ OUADRANCT.F.}

Nauman, J. W., and Kermodle, D. R., 1974, Aquatic órganisms from selected sites elong the proposed trans-Alaska plpeline corrldor, September 1970 to September 1972: U.S. Geol. Survey open-file report, $23 \mathrm{p}$.

U.s. Geological survey, 1973, Geological survey research 1973: U.S. Geol. Survey Prof. Paper 850,366 p.

\section{WAINWRIGHT QUADRANGLE}

Grantz, Arthur, Mchendrie, A. G., N1lsen, T. F., and Yorath, C. J., 1974, Selsmle reflection profiles on the continental shelf and slope between Bering Stralt and Barrow, Alaska, and Mackenzie Bay, Canada: U.S. Geol. Survey open-file rept., 51 sheets.

Grantz, Arthur, McHendrie, A. G., N1lsen, T. H., Yorath, C. I., and Phlllips, J. D., 1974, Digital magnetic tapes of single channel selsmic reflection profiles on the continental shelf and slope between Bering Strait and Barrow, Alaska, and Mackenzie Bay, Canada: Natl. Tech. Inf. Serv1ce PB-232 344, 12 p.

Ranne, W. F., Ruppel, D. B., McHendrie, A. G.; and sikore, R. F., 1974, Residual magnetic anomaly and free-air gravity anomaly profiles, 1973, on continental shelf and slope between Berlng Stralt and Barrow, Alaska, and Mackenzie Bay, Canada: U.S. Geol. Survey openfile report $74-6,6$ sheets.

\section{WISEMAN QUADRANGLE}

Alaska Division of Geological and Geophysical Surveys, 1974, Annual Report 1973: Anchorage, Alaska, 59 p.

Bottge, R. G., 1974, Potential mineral resources in selected D.2 lands: U.S. Bur. Mines open-f1le rept. 9-74, $55 \mathrm{p}$. Also released as Nat1. Tech. Inf. Service PB $227018 / A S$.

Carter, claire, ed., 1974, United States Geologleal Survey Alaska Program, 1974: U.S. Geol. Survey Clre. 700, $63 \mathrm{p.}$

Ch1lders, J. M., 1974, Flood surveys along TAPS route, Alaska: U.S. Geol. Survey open-flle report, $16 \mathrm{p}$.

Marvin, R. F., 1974, A tabulation of K-Ar, Rb-Sr, and Pb-r ages obtained from materials within the United States (Including Alaska and Bawa11) during the years 1965 through 1968: U.S. Geol. Survey open-file report, 245 p. 


\section{WISEMAN QUADRANGLE}

Muligan, J. J., 1974, Mineral resources of the trans-Alaska pipeline corridor: U.S. Bur. Mines Inf. Circ. 8626, 24 p.

Naumen, J. H., and Kernodle, D. R., 1974, Aquatic organtsms from selected sites along the proposed trans-Alaska pipeline corridor, September 1970 to September 1972: U.S. Geol. Survey open-file report, $23 \mathrm{p}$.

U.8. Geological survey, 1973, Geological survey résearch 1973: U.S. Geol. Survey Prof. Paper 850, 366 p. 